\title{
Life cycle environmental impacts of inhalers
}

DOI:

10.1016/j.jclepro.2019.117733

\section{Document Version}

Accepted author manuscript

Link to publication record in Manchester Research Explorer

\section{Citation for published version (APA):}

Jeswani, H. K., \& Azapagic, A. (2019). Life cycle environmental impacts of inhalers. Journal of Cleaner Production, 237, [117733]. https://doi.org/10.1016/j.jclepro.2019.117733

\section{Published in:}

Journal of Cleaner Production

\section{Citing this paper}

Please note that where the full-text provided on Manchester Research Explorer is the Author Accepted Manuscript or Proof version this may differ from the final Published version. If citing, it is advised that you check and use the publisher's definitive version.

\section{General rights}

Copyright and moral rights for the publications made accessible in the Research Explorer are retained by the authors and/or other copyright owners and it is a condition of accessing publications that users recognise and abide by the legal requirements associated with these rights.

\section{Takedown policy}

If you believe that this document breaches copyright please refer to the University of Manchester's Takedown Procedures [http://man.ac.uk/04Y6Bo] or contact uml.scholarlycommunications@manchester.ac.uk providing relevant details, so we can investigate your claim.

\section{OPEN ACCESS}


Journal of Cleaner Production, https://doi.org/10.1016/j.jclepro.2019.117733

\title{
Life cycle environmental impacts of inhalers
}

\author{
Harish Kumar Jeswani* and Adisa Azapagic
}

Sustainable Industrial Systems, School of Chemical Engineering and Analytical Science, The University of Manchester, Manchester, M13 9PL, UK

*Corresponding author: harish.jeswani@manchester.ac.uk

\begin{abstract}
Pressurised metered-dose inhalers are a method of choice for delivering drugs into lungs for the treatment of asthma and chronic obstructive pulmonary disease across the globe. HFC-134a and HFC-227ea propellants, which are currently used in these inhalers, have significant global warming potentials. To reduce the climate change impact of inhalers, several options are available to the industry, including alternative devices, such as dry powder inhalers and nebulisers. In addition, the manufacturers can reduce the propellant quantity per dose or use a different propellant with a lower global warming potential, such as HFC-152a. This study evaluates the life cycle environmental impacts of different types of inhaler and investigates possible scenarios to reduce their impacts. The environmental impacts are estimated through life cycle assessment, following the $\mathrm{ReCiPe}$ impact assessment method. The results suggest that HFC-152a inhaler has the lowest impacts for ten out of 14 categories considered, while the dry powder inhaler is the worst option for eight impacts; however, it has the lowest climate change and ozone depletion impacts. Considering the annual use of pressurised metered-dose and dry powder inhalers in the UK, they generate $1.34 \mathrm{Mt} \mathrm{CO}_{2}$ eq., largely due to HFC-134a inhalers. This represents $4.3 \%$ of greenhouse gas emissions of the NHS (National Health Service). Replacing HFC-134a with HFC-152a would reduce the climate change and ozone depletion impacts of inhalers in the UK by $90 \%-92 \%$. Most other environmental impacts would also decrease significantly (28\%-82\%). Switching from pressurised metered-dose inhalers to dry powder inhalers would lead to an even higher reduction in the climate change impact (96\%). However, several other impacts would increase significantly, including human toxicity, marine eutrophication and fossil depletion. Since changing propellants or replacing pressurised metered-dose inhalers with dry powder inhalers requires further research and development, pharmaceutical companies should continue to work on minimising propellant usage in inhalers and on achieving higher rates of recycling of current inhalers.
\end{abstract}

Keywords: carbon footprint; dry powder inhaler; hydrofluorocarbons; propellant; life cycle assessment; pressurised metered dose inhaler

\section{Introduction}

The healthcare sector is a significant contributor to greenhouse gas (GHG) emissions globally. It accounts for $10 \%$ of national GHG emissions in the USA (Eckelman and Sherman, 2016), $7 \%$ in Australia (Malik et al., 2018) and 4.6\% in Canada (Eckelman et al., 2018). In 2015, the sector in England emitted 26.6 Mt of GHG emissions (Sustainable Development Unit, 2016), contributing $7 \%$ to England's annual emissions of $370 \mathrm{Mt} \mathrm{CO}_{2}$ eq. (NAEI, 2018). Currently, 57\% of GHG emissions (15.2 $\mathrm{Mt} \mathrm{CO}_{2}$ eq.) from healthcare in England are related to procurement (Sustainable Development Unit, 2016). Of this, $24 \%$ (3.6 Mt $\mathrm{CO}_{2}$ eq.) is from pharmaceuticals. Pressurised metered-dose inhalers (pMDIs) are the largest single contributors to the pharmaceutical-related GHG emissions (Sustainable Development Unit, 2016).

Pressurised metered-dose inhalers were first introduced in 1956 by Riker Laboratories for the treatment of asthma and chronic obstructive pulmonary disease (COPD) (Stein and Thiel, 2017). Since then, pMDIs have played a vital role in the delivery of a number of medications through the inhalation route and continue to be the major method of choice for the delivery of drugs for the management of asthma and COPD across the globe. pMDIs rely on the driving force of propellants, which comprise the bulk of any pMDI formulation, to atomise droplets containing drug and excipients for deposition in the lungs (Ferguson et al., 2018). It is estimated that more than 630 million pMDls are manufactured each year globally, using around 10,000 tonnes of propellants (UNEP, 2014). 
Originally chlorofluorocarbons (CFC), such as ozone-depleting CFC-11, CFC-12 and CFC-114, were used as propellants in pMDIs (Myrdal et al., 2014). With the ratification of the Montreal Protocol on Substances that Deplete the Ozone Layer in 1989, which banned the use of CFCs (UNEP, 1987), an industry-wide transition to hydrofluorocarbon (HFC, also known as hydrofluoroalkane or HFA) propellants, such as HFC-134a and HFC-227ea, ensued globally. In addition to the ozone-related benefits, the move to HFCs from CFCs resulted in an order of magnitude reduction in the global warming potential (GWP) associated with propellant use (see Table S1 in the Supplementary Information). Despite that, the GWPs of HFC134a and HFC-227ea propellants are still regarded by many as high and the healthcare industry is exploring various options for further reducing the GHG emissions associated with pMDIs. Some of these options include:

- the use of alternative devices, such as dry powder inhalers (DPI) and nebulisers;

- reducing the amount of propellant used per dose; and

- using different propellants with a lower GWP in pMDIs.

DPIs and nebulisers are already in widespread use for certain drugs but it is not yet technically or economically feasible to replace pMDIs completely due to cost, technical and patient-acceptability reasons (UNEP, 2016). Techniques for reducing the amount of propellant and hence its emission into the atmosphere include reducing the size of metering valves and recovery of propellant from spent or part-consumed pMDIs. Regarding the use of different propellants, HFC-152a $(1,1,-$ difluoroethane) has been suggested as a potential replacement for current pMDI propellants and is currently being investigated by the manufacturer for its safety and formulation behaviour (Noakes and Corr, 2016).

Production of pharmaceutical products is a complex and resource-intensive process, which can have significant impacts on the environment (Parvatker et al., 2019). Pharmaceutical companies across the globe are adopting different sustainability-related practices in an attempt to minimise their impacts (Chaturvedi et al., 2017). These practices include use of green chemistry principles for the reduction or replacement of hazardous substances (Cue and Zhang, 2009), adoption of energyefficiency measures in manufacturing (Müller et al., 2014) and application of the eco-design concept in product development (Baron, 2012). Moreover, some companies are using life cycle assessment (LCA) to identify, evaluate and implement such measures (De Soete et al., 2017; Jiménez-González et al., 2011). However, often such assessments apply fast screening or streamlined methods for hotspot determination (Cespi et al., 2015; De Soete et al., 2017) rather than full LCA studies. Moreover, these assessments are often not available in the public domain. The lack of primary data provided by the pharmaceutical industry to construct life cycle inventories is also one of the most important reason for the lack of LCA studies on pharmaceutical products (De Soete et al., 2017). To address these data gaps, some studies (Parvatker et al., 2019; Ponder and Overcash, 2010) have focussed on developing life cycle inventories for active pharmaceutical ingredients (APIs). Others have assessed the LCA impacts of APIs (Brunet et al., 2014; McAlister et al., 2016; Wernet et al., 2010). Parvatker et al. (2019) also estimated cradle-to-gate GHG emissions of 20 anaesthetic drugs and found that GHG emissions of drugs varied enormously, from $11 \mathrm{~kg}$ to $3000 \mathrm{~kg} \mathrm{CO}$ eq. per $\mathrm{kg}$ of APIs, depending on the number of synthesis steps needed in the manufacturing of the drug. Since the use of organic solvents is the main hotspot in the synthesis of APIs, LCA studies have also evaluated cleaner production options with the aim of or reducing their use or replacing them (Amado Alviz and Alvarez, 2017; Leone et al., 2018).

In line with the other pharmaceutical products, there is also limited information on the environmental impacts of inhalers. Goulet et al. (2017) compared carbon footprints of a HFC-134a inhaler with a nebuliser and found that in comparison to a nebuliser, pMDI has a 2-3 times higher GWP. A study by GlaxoSmithKline (2014) found that the GWP of their HFC-134a inhalers was 17 times higher than that of DPI, while UNEP (2014) report provided GWP estimates for HFC-134a, HFC-227ea and DPIs. Unlike the previous studies which focused on GWP only, this study aims to evaluate a range of life cycle environmental impacts of pMDIs and DPIs. For pMDIs, three different propellants are considered: HFC-134a, HFC-227ea and HFC-152a. As far as the authors are aware, this is the first study to quantify the life cycle impacts of inhalers using a comprehensive set of environmental impact indicators, accompanied with sensitivity and uncertainty analyses. The impacts are estimated 
both for the individual inhalers and for their annual use, with the latter focused on UK situation. Possible options to reduce the environmental impacts of inhalers are also considered. It is hoped that the results of this research will be useful for the healthcare industry and policy makers.

The next section provides details on the different types of inhaler considered and gives an overview of the methodology used to assess the environmental impacts. The results are presented in Section 3 , followed by the conclusions and recommendations in Section 4.

\section{Methodology}

The environmental impacts have been estimated through LCA, following the ISO 14040/14044 guidelines (ISO, 2006a, b). The next sections detail the goal, scope, inventory data and the impact assessment methodology used in the study.

\subsection{Goal and scope of the study}

The aim of this study is to estimate the environmental impacts of inhaler devices used for the delivery of inhalation medicines and evaluate possible options for reducing their impacts. Two types of inhaler are considered: pMDI and DPI. Their typical designs are illustrated in Figure 1. For pMDIs, the impacts of three types of propellant are investigated: HFC-134a, HFC-227ea and HFC152a. The first two are currently used in pMDIs, while HFC-152a is seen by the pharmaceutical industry as a candidate to replace the existing propellants to reduce the climate change impact of inhalers.

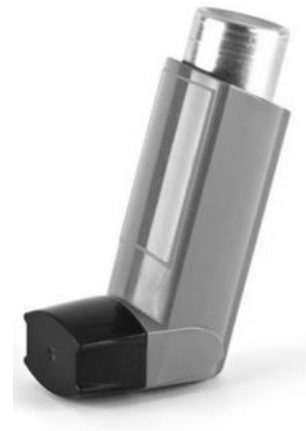

a) Pressurised metered-dose inhaler (pMDI)

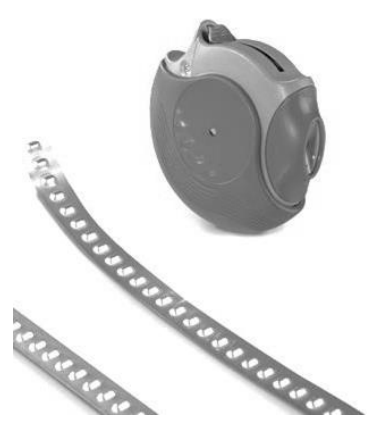

b) Dry powder inhaler (blister-based Diskus)

Figure 1 Typical design of pressurised metered-dose and dry powder inhalers

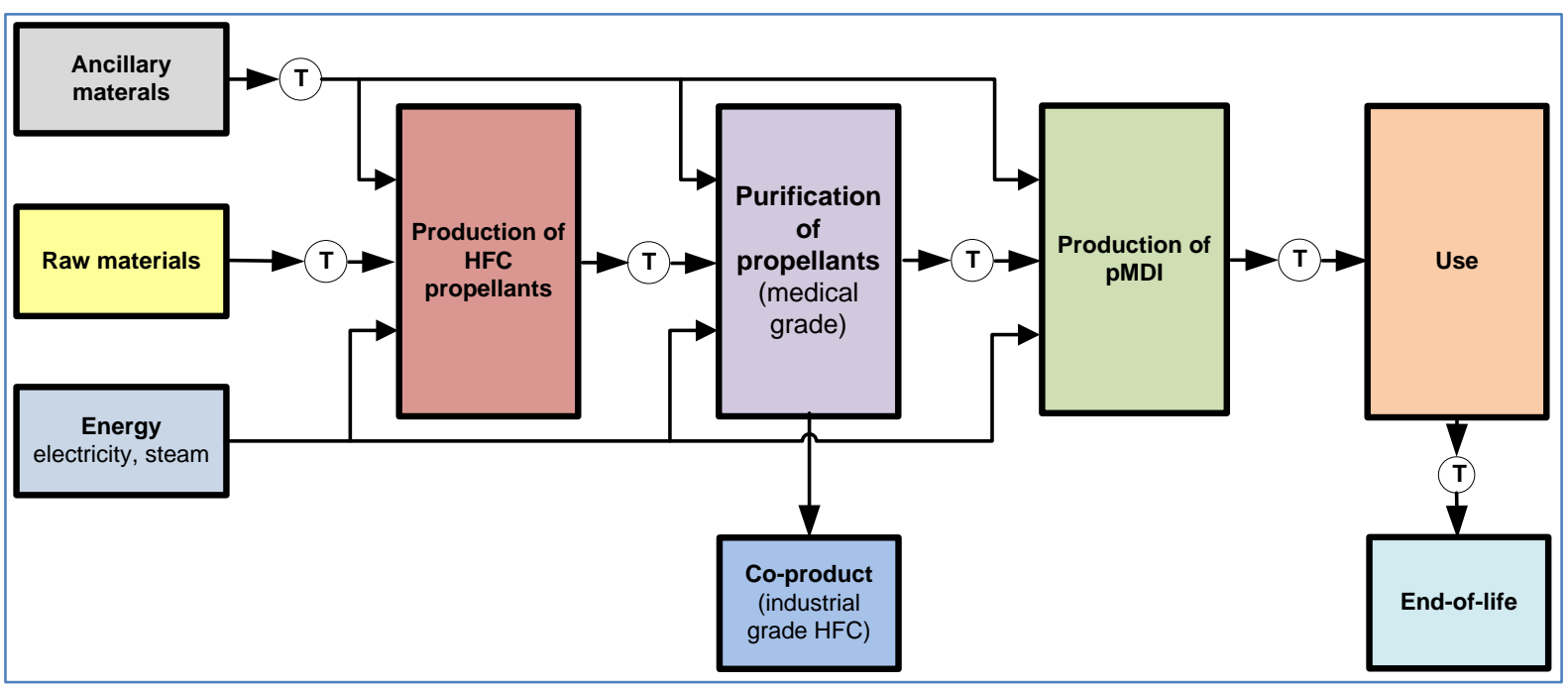

a) Pressurised metered-dose inhaler (pMDI) 


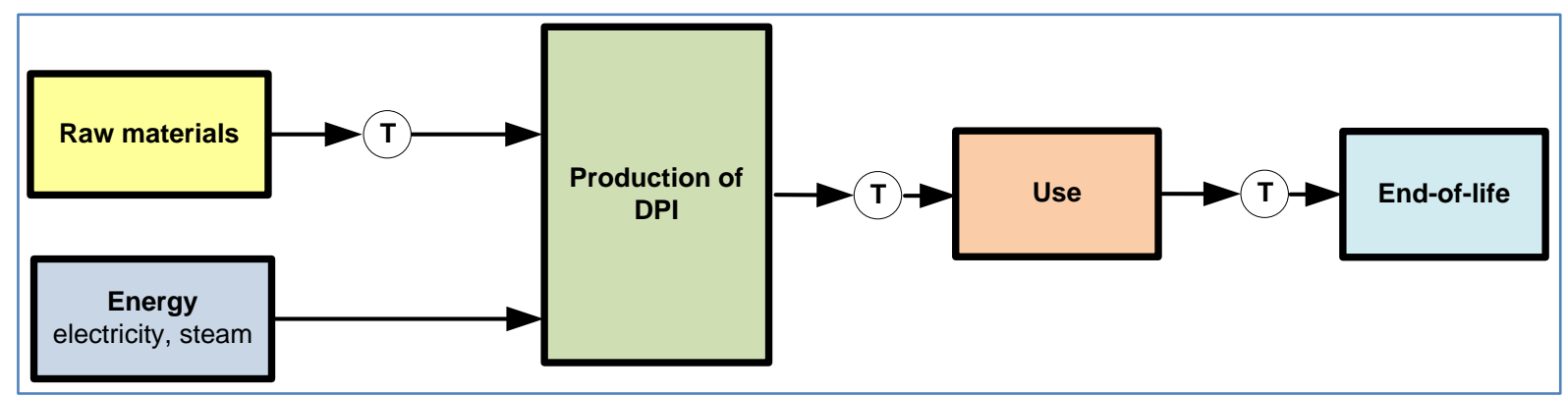

b) Dry powder inhaler (DPI)

Figure 2 Life cycle stages considered for the pMDI and DPI inhalers

The scope of the study is from 'cradle to grave' including production of the device and the propellants (for pMDIs), as well as the use and end-of-life disposal of inhalers (Figure 2). The production of APIs is not considered and it is independent of the delivery platform (inhaler type) used. The analysis is first carried out for individual inhalers, with the functional unit defined as 'delivery of 1 dose of inhaled medicine'. The results are then scaled up to consider the impacts based on the annual usage of inhalers in the UK. For the latter, various alternative scenarios for reducing the impacts are also explored.

\subsection{Inventory data}

Most of the primary data for inhalers and propellants have been obtained directly from industry, supplemented by literature where necessary. The background data are from Ecoinvent V3.3 database (Ecoinvent, 2016). This is detailed in the following sections.

\subsubsection{Pressurised metered-dose inhaler}

The pMDI device consists of three components: an inhaler device, a propellant and a drug. As mentioned earlier, the drug is not considered. For effective delivery of some drugs, co-solvents, such as ethanol and polyethylene glycol (PEG 1000), are also added in the pMDI formulation to increase drug solubility in HFC propellants, improve suspension behaviour or enhance valve function (Myrdal et al., 2014). These are all considered, as described further below.

\subsubsection{Production of pMDI device}

The pMDI device comprises a canister, an actuator, a valve, a mouthpiece and a cap. The canister is made of aluminium and, in this study, assumed to be coated with Teflon. The inhaler cap, mouthpiece, actuator and other parts are made of polypropylene, polyoxymethylene and polymethylacrylate (PMMA) as detailed in Table 1. The life cycle inventory data for the device have been obtained from a leading pharmaceutical company. The background data for materials and manufacturing have been sourced from the Ecoinvent V3.3 database (Ecoinvent, 2016).

Table 1 Inventory data for raw materials for the production of inhaler devices

\begin{tabular}{lrr}
\hline Size & $\begin{array}{c}\text { pMDI } \\
\mathbf{1 0 0} \text { doses } \\
(\mathbf{2 0 0} \text { actuations) }\end{array}$ & $\begin{array}{c}\text { DPI } \\
\mathbf{6 0} \text { doses }^{\mathbf{a}}\end{array}$ \\
\hline Aluminium & $7.6 \mathrm{~g}$ & $20 \mathrm{~g}$ \\
Teflon (for coating) & $0.004 \mathrm{~g}$ & - \\
Polypropylene & $14 \mathrm{~g}$ & $1.3 \mathrm{~g}$ \\
Polyoxymethylene & $0.4 \mathrm{~g}$ & $7.7 \mathrm{~g}$ \\
Polymethylmethacrylate & $0.006 \mathrm{~g}$ & - \\
Acrylonitrile-butadiene-styrene copolymer & - & $35.6 \mathrm{~g}$ \\
Nylon & - & $5 \mathrm{~g}$ \\
Polycarbonate & - & $2.4 \mathrm{~g}$ \\
Polyvinylchloride & - & $5 \mathrm{~g}$ \\
\hline a pMDI: Pressurised metered-dose inhaler. DPI: dry powder inhaler (blister-based Diskus). The number of doses are \\
based on a typical size of devices in the UK.
\end{tabular}




\subsubsection{Production of propellants}

An overview of the processes for the production of different propellants is provided below.

i) HFC-134a $\left(\mathrm{C}_{2} \mathrm{H}_{2} \mathrm{~F}_{4}\right)$ is produced in a two-step process from hydrofluoric (HF) acid and trichloroethylene (TCE) in the presence of $\mathrm{a}_{2} \mathrm{Cr}_{3}$ catalyst:

$\mathrm{C}_{2} \mathrm{HCl}_{3}+3 \mathrm{HF} \rightarrow \mathrm{C}_{2} \mathrm{H}_{2} \mathrm{ClF}_{3}+2 \mathrm{HCl}$

$\mathrm{C}_{2} \mathrm{H}_{2} \mathrm{ClF}_{3}+\mathrm{HF} \rightarrow \mathrm{C}_{2} \mathrm{H}_{2} \mathrm{~F}_{4}+\mathrm{HCl}$

Lime, caustic soda and nitrogen are used as ancillary materials and $\mathrm{HCl}$ is produced as a coproduct. The inventory data for the production and purification of the propellant are shown in Table 2. The data for the production of HFC-134a have been obtained from manufacturing plants in the USA and Japan, owned by Mexichem, a globally leading manufacturer of propellants. HFC-134a is further purified to the pharmaceutical grade (purity of $\geq 99.9 \%$ vol.) in the UK for use in inhalers (Figure 2). The purification process also produces industrial grade HFC-134a as a co-product.

ii) HFC-227ea $\left(\mathrm{C}_{3} \mathrm{HF}_{7}\right)$ is manufactured by hydrofluorination of hexafluoropropene $\left(\mathrm{C}_{3} \mathrm{~F}_{6}\right)$. The latter is produced through thermal conversion of tetrafluoroethylene (TFE) according to the following reactions:

$$
\begin{aligned}
& 3 \mathrm{C}_{2} \mathrm{~F}_{4} \stackrel{\text { Heat }}{\longrightarrow} 2 \mathrm{C}_{3} \mathrm{~F}_{6} \\
& \mathrm{C}_{3} \mathrm{~F}_{6}+\mathrm{HF} \rightarrow \mathrm{C}_{3} \mathrm{HF}_{7}
\end{aligned}
$$

Table 3 provides the inventory data for the production of HFC-227ea, which have been obtained from literature (Banks et al., 1998). Energy use and other data for further processing of HFC-227ea from the industrial to pharmaceutical grade (purity of $\geq 99.99 \%$ vol.) are assumed to be similar to that of HFC-134a.

iii) HFC-152a $\left(\mathrm{C}_{2} \mathrm{H}_{4} \mathrm{~F}_{2}\right)$ is made from vinyl chloride monomer and hydrofluoric acid as follows:

$$
\begin{aligned}
& \mathrm{C}_{2} \mathrm{H}_{3} \mathrm{Cl}+\mathrm{HF} \rightarrow \mathrm{C}_{2} \mathrm{H}_{4} \mathrm{ClF} \\
& \mathrm{C}_{2} \mathrm{H}_{4} \mathrm{ClF}+\mathrm{HF} \rightarrow \mathrm{C}_{2} \mathrm{H}_{4} \mathrm{~F}_{2}+\mathrm{HCl}
\end{aligned}
$$

Caustic soda, $\mathrm{SnCl}_{4}$ catalyst and nitrogen are used as ancillaries. As can be seen from the second reaction above, this process also produces $\mathrm{HCl}$ as a co-product. Like HFC-134a, HFC-152a also has

\begin{tabular}{|c|c|c|c|c|c|}
\hline Inputs & Amount & Unit & Emissions & Amount & Unit \\
\hline \multicolumn{6}{|l|}{ Production $^{\mathrm{a}}$} \\
\hline Hydrofluoric acid & 780 & $\mathrm{~kg} / \mathrm{t}$ & Hydrofluoric acid & 35 & $\mathrm{~g} / \mathrm{t}$ \\
\hline Trichloroethylene & 1290 & $\mathrm{~kg} / \mathrm{t}$ & Hydrochloric acid & 32 & $\mathrm{~g} / \mathrm{t}$ \\
\hline Catalyst $\left(\mathrm{Cr}_{2} \mathrm{O}_{3}\right)$ & 1 & $\mathrm{~kg} / \mathrm{t}$ & HFC-134a & 106 & $\mathrm{~g} / \mathrm{t}$ \\
\hline Lime & 48 & $\mathrm{~kg} / \mathrm{t}$ & HFC-133a & 86 & $\mathrm{~g} / \mathrm{t}$ \\
\hline Caustic soda (50\%) & 23 & $\mathrm{~kg} / \mathrm{t}$ & Carbon monoxide & 66 & $\mathrm{~g} / \mathrm{t}$ \\
\hline Nitrogen & 22 & $\mathrm{~kg} / \mathrm{t}$ & Trichloroethylene & 100 & $\mathrm{~g} / \mathrm{t}$ \\
\hline Water & 2 & $\mathrm{~m}^{3} / \mathrm{t}$ & n-hexane & 14 & $\mathrm{~g} / \mathrm{t}$ \\
\hline Electricity & 830 & $\mathrm{kWh} / \mathrm{t}$ & Volatile organic compounds & 389 & $\mathrm{~g} / \mathrm{t}$ \\
\hline $\begin{array}{l}\text { Heat (natural gas and liquefied petroleum } \\
\text { gas) }\end{array}$ & 21,500 & $\mathrm{MJ} / \mathrm{t}$ & & & \\
\hline \multicolumn{6}{|l|}{ Purification } \\
\hline Nitrogen & 15 & $\mathrm{~kg} / \mathrm{t}$ & HFC-134a (fugitive) & 770 & $\mathrm{~g} / \mathrm{t}$ \\
\hline Electricity (MJ) & 200 & $\mathrm{kWh} / \mathrm{t}$ & & & \\
\hline Heat (MJ) & 5300 & $\mathrm{MJ} / \mathrm{t}$ & & & \\
\hline
\end{tabular}
to be purified to the pharmaceutical grade ( $\geq 99.9 \%$ vol.). Table 4 details the inventory data for the production of HFC-152a, obtained from Mexichem.

Table 2 Inventory data for the production of HFC-134a 
Table 3 Inventory data for the production of HFC-227ea (Banks et al., 1998)

\begin{tabular}{|c|c|c|c|c|c|}
\hline Inputs & Amount & Units & Emissions & Amount & Units \\
\hline \multicolumn{6}{|l|}{ Production $^{\mathrm{a}}$} \\
\hline Hydrofluoric (HF) acid & 98 & $\mathrm{~kg} / \mathrm{t}$ & Tetrafluoroethylene & 13.3 & $\mathrm{~kg} / \mathrm{t}$ \\
\hline Tetrafluoroethylene & 1123 & $\mathrm{~kg} / \mathrm{t}$ & Hexafluoropropylene & 29.9 & $\mathrm{~kg} / \mathrm{t}$ \\
\hline Heat (natural gas) & 3250 & $\begin{array}{l}\mathrm{MJ} / \mathrm{t} \\
\quad \text { Puri }\end{array}$ & $\begin{array}{l}\text { HFC-227ea } \\
\text { fication }\end{array}$ & 7.5 & $\mathrm{~kg} / \mathrm{t}$ \\
\hline $\begin{array}{l}\text { Nitrogen } \\
\text { Electricity } \\
\text { Heat }\end{array}$ & $\begin{array}{r}15 \\
200 \\
5300\end{array}$ & $\begin{array}{l}\mathrm{kg} / \mathrm{t} \\
\mathrm{kWh} / \mathrm{t} \\
\mathrm{MJ} / \mathrm{t}\end{array}$ & HFC-227ea (fugitive) & 770 & $g / t$ \\
\hline
\end{tabular}

\subsubsection{Amount of propellant}

The amount of propellant used in pMDIs varies widely due to several factors, including the size of inhaler, type of drug, type of propellant and the use of excipient and drug. pMDI inhalers are available in different sizes. The most commonly prescribed size in the UK for HFC-134a inhalers is 200 actuations (100 doses), while for HFC-227ea, it is 120 actuations (60 doses), as shown in Table 5. Although many pMDIs use a single actuation per dose, it is common for a pMDI dose to consist of two puffs (actuations). Table 6 provides the quantities of propellant for different inhalers, which have been obtained from the respective Patient Information Leaflets provided by drug manufacturers. In the base-case analysis, the weighted average quantities of the propellants in inhalers in the UK have been used. As can be seen in Table 6, these correspond to $166.7 \mathrm{mg} / \mathrm{dose}$ for HFC-134a and 162.7 $\mathrm{mg} / \mathrm{dose}$ for HFC-227ea. Since there are no equivalent values for HFC-152a as it is still not used in inhalers, its required quantity per dose has been estimated based on the amount of HFC-134a currently used in pMDIs. Assuming an approximately constant number of moles of propellant in a pMDI, the equivalent amount of HFC-152a required would be $34 \%$ lower than that of HFC-134a, i.e. $110 \mathrm{mg} / \mathrm{dose}$. Since the propulsion effect of the propellant is based on the volume of gas generated from a metered-dose of liquid propellant, an assumption of molar equivalence is correct.

Table 4 Inventory data for the production of HFC-152a

\begin{tabular}{|c|c|c|c|c|c|}
\hline Inputs & Amount & Units & Emissions & Amount & Units \\
\hline \multicolumn{6}{|l|}{ Production $^{\mathrm{a}}$} \\
\hline Hydrofluoric acid & 638 & $\mathrm{~kg} / \mathrm{t}$ & HFC-152a & 447 & $g / t$ \\
\hline Vinyl chloride monomer & 997 & $\mathrm{~kg} / \mathrm{t}$ & & & \\
\hline Catalyst $\left(\mathrm{SnCl}_{4}\right)$ & 1 & $\mathrm{~kg} / \mathrm{t}$ & & & \\
\hline Lime & 48 & $\mathrm{~kg} / \mathrm{t}$ & & & \\
\hline Caustic soda (50\%) & 35 & $\mathrm{~kg} / \mathrm{t}$ & & & \\
\hline Nitrogen & 53 & $\mathrm{~kg} / \mathrm{t}$ & & & \\
\hline Water & 2 & $\mathrm{~m}^{3 / \mathrm{t}}$ & & & \\
\hline Electricity & 540 & $\mathrm{kWh} / \mathrm{t}$ & & & \\
\hline Heat (natural gas) & 3900 & $\mathrm{MJ} / \mathrm{t}$ & & & \\
\hline \multicolumn{6}{|l|}{ Purification } \\
\hline Nitrogen & 15 & $\mathrm{~kg} / \mathrm{t}$ & HFC-152a (fugitive) & 770 & $g / t$ \\
\hline Electricity & 200 & $\mathrm{kWh} / \mathrm{t}$ & & & \\
\hline Heat & 5300 & $\mathrm{MJ} / \mathrm{t}$ & & & \\
\hline
\end{tabular}

\subsubsection{Dry powder inhaler}

DPIs, as their name suggests, contain and deliver the drug as a dry powder for respiratory therapy. The medication is either delivered through blisters, capsules or cartridges. There are numerous designs of devices currently available (Kou and Cao, 2016). In this study, a blister-based Diskus DPI is considered. The DPI device is made of different types of plastics, such as acrylonitrile butadiene styrene (ABS), polycarbonate, polypropylene, and polyoxymethylene, while blisters are made of polyvinyl chloride (PVC), aluminium foil and nylon. DPIs are also available in various sizes and the most common size prescribed in the UK is 60 doses (Table 5). The inventory data for the 
materials used for the manufacture of DPI in Table 1 are for a 60-dose Diskus inhaler, which have been obtained from the manufacturer.

Table 5 Annual usage of inhalers in the UK by type and size ${ }^{a}$

\begin{tabular}{|c|c|c|c|c|c|c|}
\hline Inhaler type & $\begin{array}{c}\text { Size } \\
\text { (actuations) }\end{array}$ & $\begin{array}{c}\text { England } \\
\text { (NHS England, } \\
\text { 2017) }\end{array}$ & $\begin{array}{c}\text { Scotland } \\
\text { (NHS Scotland, } \\
\text { 2017) }\end{array}$ & $\begin{array}{c}\text { Wales } \\
\text { (NHS Wales, } \\
\text { 2017) }\end{array}$ & $\begin{array}{l}\text { Northern Ireland } \\
\text { (NHS Northern } \\
\text { Ireland, 2017) }\end{array}$ & Total UK \\
\hline \multirow[t]{5}{*}{ HFC-134a } & 60 & 21,245 & 802 & 951 & 1,084 & 24,142 \\
\hline & 100 & 43,793 & 1,275 & 690 & 250 & 46,108 \\
\hline & 120 & $8,351,991$ & 766,849 & 600,150 & 26,429 & $9,745,539$ \\
\hline & 200 & $35,827,775$ & $3,681,420$ & $2,392,031$ & $1,401,577$ & $43,303,003$ \\
\hline & Sub total & $44,244,804$ & $4,450,346$ & 2,993,822 & $1,429,341$ & $53,118,793$ \\
\hline \multirow[t]{3}{*}{ HFC-227ea } & 112 & 16,355 & 2,292 & 793 & 209 & 19,761 \\
\hline & 120 & 776,708 & 75,062 & 88,054 & 122,990 & $1,062,934$ \\
\hline & Sub total & 793,063 & 77,354 & 88,847 & 123,199 & $1,082,695$ \\
\hline \multirow[t]{8}{*}{ DPI } & 30 & $1,040,074$ & 79,764 & 132,970 & 97,344 & $1,350,182$ \\
\hline & 50 & 95,384 & 11,833 & 2,989 & 2,965 & 113,221 \\
\hline & 60 & $6,135,470$ & 940,289 & 305,555 & 301,142 & $7,682,516$ \\
\hline & 100 & $1,097,478$ & 239,987 & 86,244 & 54,271 & $1,478,080$ \\
\hline & 120 & $3,463,433$ & 354,575 & 261,910 & 108,502 & $4,188,540$ \\
\hline & 200 & 466,050 & 164,534 & 58,865 & 36,122 & 725,771 \\
\hline & Sub total & $12,297,889$ & $1,790,982$ & 848,533 & 600,346 & $15,538,310$ \\
\hline & Grand total & $57,335,756$ & $6,318,682$ & $3,931,202$ & $2,152,886$ & $69,739,798$ \\
\hline
\end{tabular}

${ }^{a}$ Prescription data for the year 2016.

\subsubsection{Other data and assumptions}

Propellant leakage in the manufacture of pMDI is assumed to be 1\% (Enviros March, 2000). After their usage, both types of inhaler are assumed to be disposed of as municipal solid waste (MSW). In the UK, 35\% of non-recycled MSW is landfilled and 65\% is incinerated with energy recovery (EC, 2018). It is assumed that all of the unused propellants are released into the atmosphere from the pMDIs during their usage or disposal.

Containers and packaging materials for the raw materials and propellants are not considered, since they are reused. Secondary packaging of inhalers is also excluded. The transport distances for the raw materials have been estimated based on their origin and transport modes provided by Mexichem. A transport distance of $200 \mathrm{~km}$ has been assumed for the transport of inhalers from a factory to a pharmacy. Ancillary materials and end-of-life waste are assumed to be transported over a distance of $100 \mathrm{~km}$.

The impacts of the pharmaceutical and industrial grades of HFCs have been allocated on an economic basis. According to the data from industry, the pharmaceutical-grade HFCs have a $30 \%$ higher market value than the industrial grade. It is assumed that $\mathrm{HCl}$ co-produced with $\mathrm{HFCs}$ has no economic value and hence all the burdens have been allocated to the HFCs. However, since the price of $\mathrm{HCl}$ fluctuates with demand, the economic allocation using the average annual price is considered in the sensitivity analysis to assess the influence of the above assumption on the results.

\subsection{Impact assessment}

The GaBi 8.7 software (Thinkstep, 2018) has been used for system modelling and estimating the impacts, applying the ReCiPe 2016 V1.1 impact assessment method (Huijbregts et al., 2017). The following 14 impact categories are considered: global warming potential (GWP), fossil depletion (FD), metal depletion (MD), terrestrial acidification (TA), freshwater eutrophication (FE), marine eutrophication (ME), human toxicity - cancer (HTc) and human toxicity - non-cancer (HTnc), freshwater ecotoxicity (FET), marine ecotoxicity (MET), terrestrial ecotoxicity (TET), ozone depletion (OD), photochemical oxidants formation - human health (POFh) and photochemical oxidants formation - ecosystem (POFe). For a brief overview of these impacts, see the Supplementary Information. 
Table 6 Propellant quantities in pMDls

\begin{tabular}{|c|c|c|c|c|c|c|}
\hline Drug & Brand & $\begin{array}{c}\text { Size } \\
\text { (actuations) }^{a}\end{array}$ & $\begin{array}{l}\text { No. of devices used } \\
\text { per year in the UK }\end{array}$ & $\begin{array}{l}\text { Propellant } \\
\text { (g/pMDI) }^{\mathrm{b}}\end{array}$ & $\begin{array}{l}\text { Propellant } \\
\text { (mg/dose) }^{\mathrm{b}, \mathrm{c}}\end{array}$ & Other excipients $^{b}$ \\
\hline \multicolumn{7}{|l|}{ HFC-134a } \\
\hline \multirow{4}{*}{ Salbutamol } & Generic & 200 & $19,912,494$ & 17.98 & 179.8 & - \\
\hline & Ventolin® & 200 & $10,995,250$ & 17.98 & 179.8 & - \\
\hline & Salamol® & 200 & $2,421,630$ & 16.54 & 165.4 & Ethanol \\
\hline & Airomir® & 200 & 412,702 & 5.92 & 59.2 & Oleic acid, ethanol \\
\hline \multirow[t]{2}{*}{ Ipratropium bromide } & Generic & 200 & 595,194 & 10.90 & 109.0 & Water, citric acid, ethanol \\
\hline & Atrovent ${ }^{\circledR}$ & 200 & 119,361 & 10.90 & 109.0 & Water, citric acid, ethanol \\
\hline \multirow[t]{2}{*}{ Beclometasone dipropionate } & Qvar® & 200 & $1,877,413$ & 11.18 & 111.8 & Glycerol, ethanol \\
\hline & Clenilß & 200 & $6,830,174$ & 11.18 & 111.8 & Glycerol, ethanol \\
\hline Beclometasone / formoterol & Fostair® & 120 & $3,510,001$ & 11.16 & 186.0 & $\mathrm{HCl}$, ethanol \\
\hline \multirow[t]{2}{*}{ Fluticasone propionate } & Seretide $\AA$ & 120 & $3,278,659$ & 11.97 & 199.5 & - \\
\hline & Others & 120 & $2,227,070$ & 11.97 & 199.5 & Ethanol \\
\hline \multirow[t]{2}{*}{ Salmeterol } & Neovent ${ }^{\circledR}$ & 120 & 577,165 & 11.97 & 199.5 & Ethanol, E322 \\
\hline & Others & 120 & 202,200 & 11.97 & 199.5 & Ethanol, E322 \\
\hline \multirow[t]{3}{*}{ Ciclesonide } & Alvesco® & 120 & 31,504 & 8.42 & 140.3 & Ethanol \\
\hline & Generic & 120 & 3,059 & 8.42 & 140.3 & Ethanol, E322 \\
\hline & Alvesco® & 60 & 24,261 & 5.61 & 187.1 & Ethanol, E322 \\
\hline Formoterol Fumarate & Atimos Modulite ${ }^{\circledR}$ & 100 & 45,756 & 8.42 & 168.4 & Ethanol \\
\hline Weighted average & & & & & 166.7 & \\
\hline \multicolumn{7}{|l|}{ HFC-227ea } \\
\hline Fluticasone propionate & Flutiform® & 120 & $1,055,634$ & 9.64 & 160.7 & Ethanol, sodium cromoglicate \\
\hline Budesonide & Symbicort@ & 120 & 7,226 & 10.15 & 169.2 & Macrogol 1000, K30 \\
\hline Sodium cromoglicate & Intalß & 112 & 12,187 & 15.31 & 273.4 & Macrogol 600, levomenthol, K30 \\
\hline Nedocromil sodium & Tilade® & 112 & 7,412 & 15.31 & 273.4 & PEG 600, K30 \\
\hline Weighted average & & & & & 162.7 & \\
\hline
\end{tabular}

a Based on prescription data in the UK for the year 2016.

b Obtained from Patient Information Leaflets provided by respective drug manufacturers

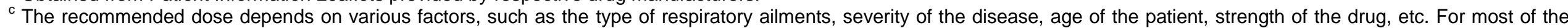
conditions, generally two puffs (actuations) per dose are recommended but the dosage can vary from one puff (for mild conditions) to four puffs (for severe conditions). 


\section{Results and discussion}

\subsection{Environmental impacts of inhalers}

This section discusses and compares the impacts of individual inhalers, based on the functional unit of 1 dose. The total impacts for each inhaler type are presented in Figure 3, with the contribution of different life cycle stages given in Figure 4. As can be seen in Figure 3, the HFC152a pMDI has the lowest impacts for ten impact categories, DPI for two and HFC-134a and HFC227 ea for the remaining two. However, the DPI is the worst option for eight impacts, followed by the HFC-227ea pMDI with six highest impacts. These findings are discussed below in more detail for each impact category in turn.

\subsubsection{Global warming potential (GWP)}

As can be seen in Figure 3, the GWP of 1 dose of the HFC-227ea pMDI is the highest, estimated at $697 \mathrm{~g} \mathrm{CO}_{2}$ eq. This is 34 and 13 times higher than the GWP of the HFC-152a and HFC-134a inhalers, respectively. The lowest impact is found for the DPI with $9 \mathrm{~g} \mathrm{CO}_{2}$ eq./dose, 2.4 times lower than the GWP of the HFC-152a inhaler, the best pMDI option.

For the pMDIs, the main hotspot is the emission of propellants to the atmosphere during the use stage (Figure 4), contributing $98 \%$ to the GWP of the HFC-134a inhaler and $90 \%$ for the impact of the HFC-152a and HFC-227ea inhalers. This is due to the relatively high GWP of the propellants, which are 167 to 1,550 times higher than that of $\mathrm{CO}_{2}$ (Table S1). For the DPI, the raw materials are the dominant contributors (70\%), followed by the production process $(22 \%)$. The contributions of transport and waste disposal are negligible across the inhalers.

\subsubsection{Fossil and metal depletion (FD and MD)}

The HFC-152a inhaler has the lowest depletion of fossil resources, estimated at $0.7 \mathrm{~g}$ oil eq./dose; this is $75 \%$ lower than that of the DPI, which is the worst option for this impact, and $35-40 \%$ lower than the pMDIs with the other two types of propellant. The raw materials are the major contributor to FD for all the inhalers.

The HFC-152a pDMI also has the lowest metal depletion (3.9 mg Cu eq./dose) while the HFC227ea variant is the worst alternative $(10.9 \mathrm{mg} \mathrm{Cu}$ eq./dose). The raw materials used for the production of propellants and the canister are the main hotspots for the pMDIs. In the case of DPI, beside the raw materials, the production process and waste disposal are also significant contributors (Figure 4).

\subsubsection{Terrestrial acidification (TA)}

TA of the HFC-152a inhaler, estimated at $7.4 \mathrm{mg} \mathrm{SO}_{2} /$ dose, is $55-60 \%$ lower than all the other inhalers considered. Raw materials are also the main hotspot for this impact across the inhalers. In the case of HFC-152a, the production of HF accounts for $50 \%$ of the impact, while for the HFC227ea, TFE contributes to $76 \%$ of the total. For the HFC-134a, HF and TCE cause $38 \%$ of TA each. The main contributors to the TA of the DPI are plastic materials (ABS and PVC) used for the production of the device and aluminium for the blister pack. The contribution of heat and electricity used in the production process is also significant (35\%) for the DPI.

\subsubsection{Freshwater and marine eutrophication (FE and ME)}

Both of these impacts are the highest for the DPI and the lowest for the HFC-152a inhaler. The FE of the HFC-152a pMDI is around 3.5 times lower than that of the HFC-227ea pMDI and DPI. This difference is even starker for ME, for which the DPI has 20 times higher impact than the HFC-152a inhaler. The main reasons for the high FE of the DPI are the phosphate emissions from the process wastewater and for the ME, nylon and ABS. 


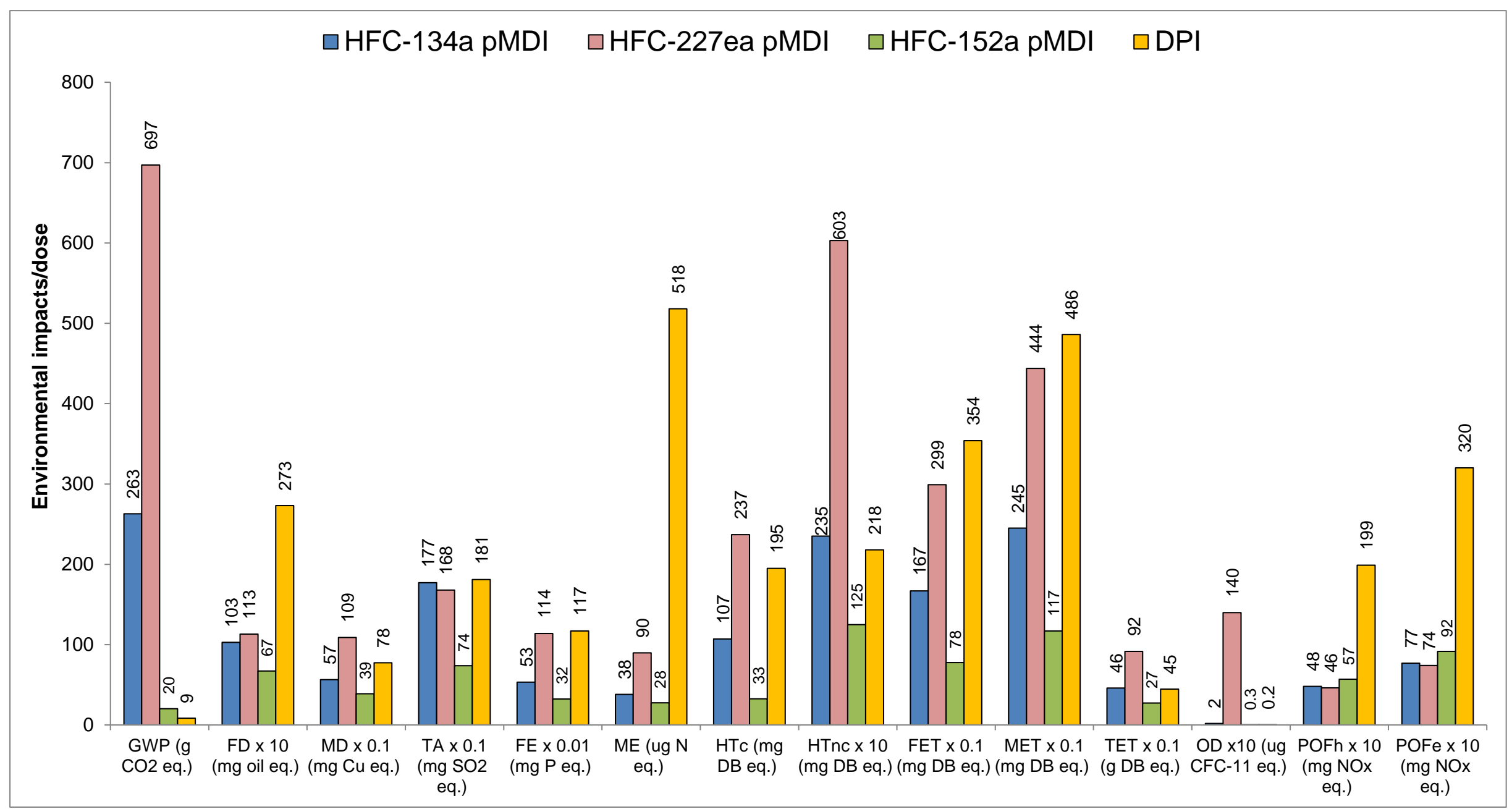

Figure 3 Life cycle environmental impacts of inhalers

[pMDI: pressurised metered-dose inhaler. DPI: dry powder inhaler. GWP: global warming potential; FD: fossil depletion; MD: metal depletion; TA: terrestrial acidification; FE: freshwater eutrophication; ME: marine eutrophication; HTc: human toxicity cancer; ; HTnc: human toxicity non-cancer FET: freshwater ecotoxicity: MET: marine ecotoxicity; TET: terrestrial ecotoxicity; OD: ozone depletion; POFh: photochemical oxidants formation - human health; POFe: photochemical oxidants formation - ecosystem. Some impacts have been scaled to fit and should be multiplied by the factor shown on the $x$-axis to obtain the original values.] 


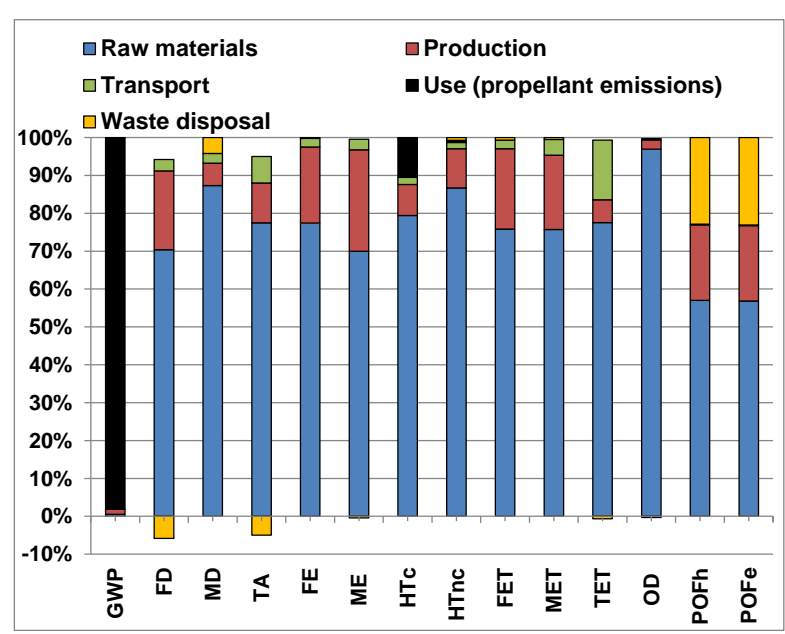

a) HFC-134a pMDI

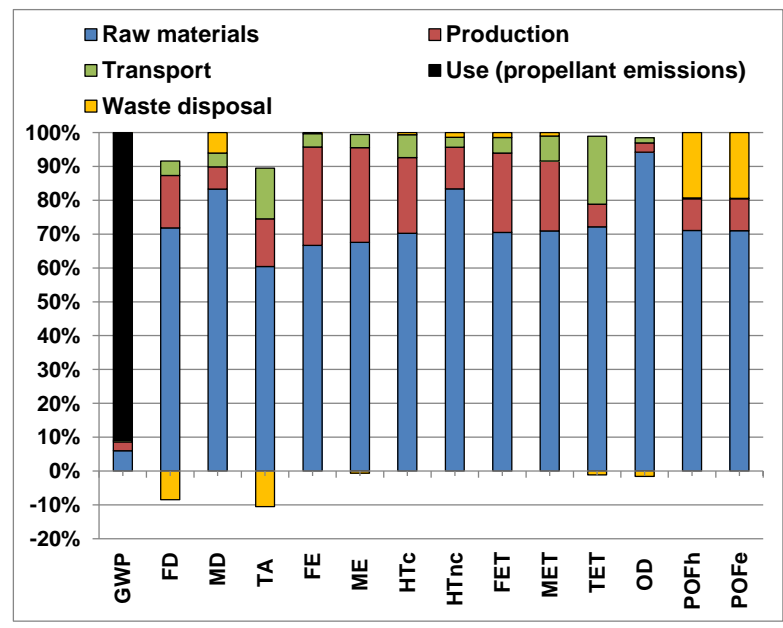

c) HFC-152a pMDI

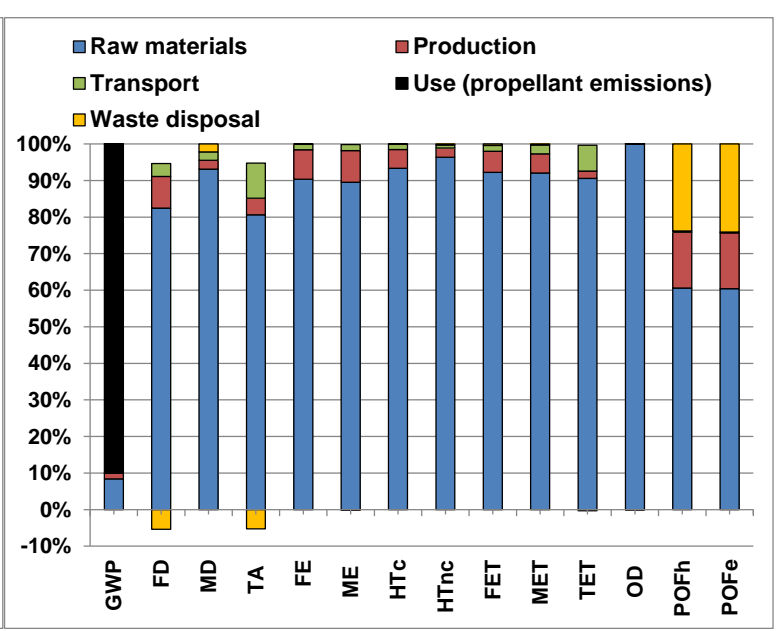

b) HFC-227ea pMDI

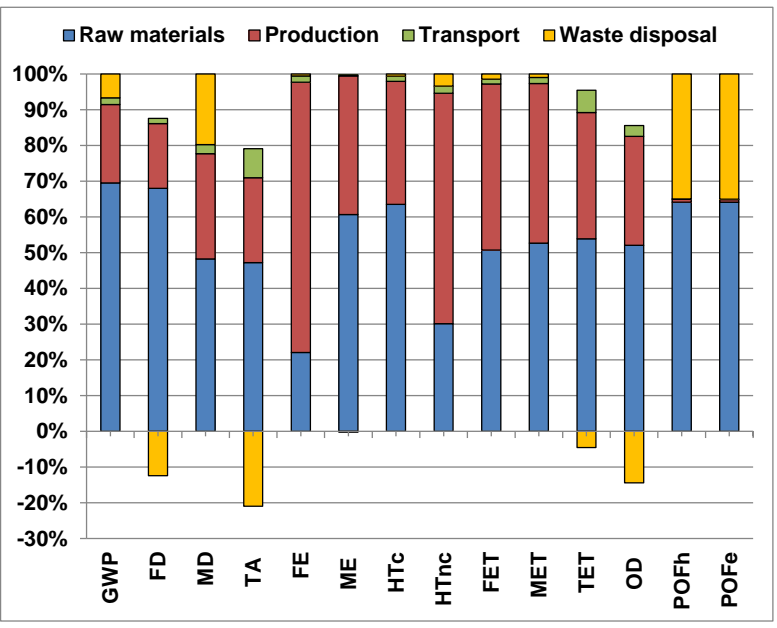

d) DPI

Figure 4 Contribution of different life cycle stages to the impacts of inhalers

[For the impacts nomenclature, see Figure 3].

\subsubsection{Human toxicity potential - cancer and non-cancer (HTc and HTnc)}

The HFC-152a inhaler is also the best option for these impacts, with HTc and HTnc around five and seven times lower, respectively, than the worst alternative - HFC-227ea. The DPI follows closely the HFC-227ea for HTc, with the impact six times higher than that of the HFC-152a inhaler. For HTnc, the DPI and HFC-134a have a similar impact, around 40\% higher than HFC-152a. Raw materials are the main hotspots for all the inhalers; for the DPI, manufacture (injection moulding) of the device is also a significant contributor (Figure 4).

\subsubsection{Ecotoxicity potentials (FET, MET and TET)}

The HFC-152a pMDI has the lowest impacts for all three categories. The DPI is the worst alternative for FET and MET, followed closely by HFC-227ea. In the case of TET, HFC227ea has a three times higher impact than HFC-152a and two times greater than DPI and HFC-134a. Raw materials are the main hotspot for all these impacts across the inhalers. For the DPI, injection moulding is also an important contributor.

\subsubsection{Ozone layer depletion (OD)}

The lowest OD is estimated for the HFC-152a pMDI, 420 times lower than the highest value estimated for the HFC-227ea inhaler. Its impact is also a factor of five smaller than that of HFC-134a. The high OD for these two inhalers is due to halogenated organic compounds 
emitted during the production of tetrafluoroethylene and trichloroethylene, respectively, used in the manufacture of the propellants.

\subsubsection{Photochemical oxidants formation - human health and ecosystem (POFh and POFe)} Both POF impacts are 3.5-5 times higher for the DPI than for the other inhalers (Figure 3 ). This is largely due to the release of waste heat from the raw materials production and waste disposal processes. The HFC-227ea inhaler has the lowest POF impacts, followed closely by HFC-134a.

\subsubsection{Sensitivity analysis}

The sensitivity analysis explores the effect on the results of the following three aspects:

- the amount of propellants used in inhalers;

- using system expansion instead of economic allocation for pharmaceutical and industrial grades of HFCs; and

- using economic allocation between $\mathrm{HFCs}$ and $\mathrm{HCl}$ instead of allocating all impacts to HFCs.

\subsubsection{Amount of propellant used in inhalers}

As indicated in Table 6, the amount of propellants in the currently available inhalers varies significantly, either due to the size or design of the device or due to formulation differences. Given the significant contribution of the propellants to the impacts, the sensitivity analysis considers the effect on the results of different quantities of propellants in inhalers. As mentioned earlier, the weighted average amounts of propellants used in inhalers in the UK have been considered in the base case, which is equivalent to $166.7 \mathrm{mg}$ of propellant/dose for the HFC-134a pMDI. However, as shown in Table 6, some inhalers contain much less propellant. For example, Airomir ${ }^{\circledR}$ has only $59 \mathrm{mg}$ of HFC-134a/dose. On the other hand, small-size Ventolin® inhaler with 30 doses $^{1}$ uses $267 \mathrm{mg}$ of HFC-134a per one dose (GlaxoSmithKline, 2009). Therefore, these two values, which represent the minimum and maximum values in the range of the quantities of HFC-134a found on the market are considered within the sensitivity analysis. In the case of HFC-227ea, the minimum and maximum values of propellant for the inhalers found on the market vary from $161 \mathrm{mg}$ to 273 $\mathrm{mg}$ (Table 6). These values are also considered in the sensitivity analysis.

As shown in Figure 5, if the amount of propellant is increased by $60 \%$ on the base case ('high-charge pMDl' as in the small-size Ventolin®), all impacts increase by 35-60\%, except for the two POF impacts which go up by $5 \%$. However, if the amount of propellant in pMDIs is reduced by $65 \%$ ('low-charge pMDI' as in Airomir $尺$ ), the impacts decrease by $22-64 \%$. The effect on the impacts is much smaller for a low-charge HFC-227ea pMDI (not shown in a figure for brevity), reducing the impacts by only $0.2-2 \%$ - this is due to a small difference $(1 \%)$ between the base-case and the minimum charge found on the market. However, increasing the charge of HFC-227ea by $67 \%$ increases the impacts by $12-68 \%$ compared to the base case. Therefore, most impacts are highly sensitive to this variable, suggesting that they can be mitigated by reducing the amount of propellant in inhalers.

\subsubsection{System expansion instead of economic allocation}

In the base case, economic allocation has been used to allocate the environmental burdens between the pharmaceutical and industrial grades of HFCs in the purification process. To assess the influence of this assumption on the results, system expansion or the 'avoided burdens' approach is considered in the sensitivity analysis. For this purpose, it is assumed that the environmental burdens of industrial grade HFC are similar to the burdens of HFC before the purification step. These burdens are credited for the production of industrial grade of HFC. In other words, all energy use and emissions of the purification process are allocated to the pharmaceutical grade HFC. The results in Figure 6 show that this

\footnotetext{
${ }^{1}$ Not shown in Table 6 as this size was not available that year (2016).
} 
assumption leads to a very small change in the impacts $(0.1-7 \%)$. Hence, the choice of allocation method has no significant effect on the results.

\subsubsection{Economic allocation between HFCs and $\mathrm{HCl}$}

It has been assumed in the base case that $\mathrm{HCl}$ co-produced with HFC-134a and HFC-152a has no economic value and hence all the burdens have been allocated to the HFCs. In the sensitivity analysis, economic allocation is considered based on the average factory gate prices of HFC-134a, HFC-152a and $\mathrm{HCl}$ (confidential). On average, HFC-134a and HFC$152 \mathrm{a}$ are 102 and 92 times more valuable than $\mathrm{HCl}(36 \%)$, respectively.

As can be seen in Table 7, most impacts of HFCs change by $1 \%-3 \%$, with the exception of GWP, POFh and POFe which are not affected. For HFC-152a inhaler, OD also remains unchanged. Thus, the effect on the results of allocating the impacts to $\mathrm{HCl}$ is very small.

Table 7 The effect on impacts of HFC-134a and HFC-152a inhalers of using economic allocation for $\mathrm{HCl}$

\begin{tabular}{|c|c|c|c|c|c|c|}
\hline \multirow[b]{2}{*}{ Impacts } & \multicolumn{3}{|c|}{ HFC-134a pMDI } & \multicolumn{3}{|c|}{$\begin{array}{c}\text { HFC-152a pMDI } \\
\end{array}$} \\
\hline & $\begin{array}{c}\text { No } \\
\text { allocation } \\
\text { for } \mathrm{HCl} \\
\text { (base case) }\end{array}$ & $\begin{array}{l}\text { Economic } \\
\text { allocation }\end{array}$ & $\begin{array}{l}\text { Change } \\
\text { relative to } \\
\text { the base } \\
\text { case }(\%)^{\mathrm{a}}\end{array}$ & $\begin{array}{c}\text { No } \\
\text { allocation } \\
\text { for } \mathrm{HCl} \\
\text { (base case) }\end{array}$ & $\begin{array}{l}\text { Economic } \\
\text { allocation }\end{array}$ & $\begin{array}{c}\text { Change } \\
\text { relative to } \\
\text { the base } \\
\text { case }(\%)^{a}\end{array}$ \\
\hline GWP (g CO 2 eq./dose) & 263.0 & 263.0 & $0 \%$ & 20.3 & 20.3 & $0 \%$ \\
\hline FD (mg oil eq./dose) & $1,030.0$ & $1,020.0$ & $-1 \%$ & 671.0 & 667.0 & $-1 \%$ \\
\hline MD (mg Cu eq./dose) & 5.7 & 5.5 & $-2 \%$ & 3.9 & 3.8 & $-1 \%$ \\
\hline $\mathrm{TA}$ (mg SO 2 eq./dose) & 17.7 & 17.3 & $-2 \%$ & 7.4 & 7.3 & $-1 \%$ \\
\hline $\mathrm{FE}(\mu \mathrm{g} \mathrm{P}$ eq./dose) & 533.0 & 521.0 & $-2 \%$ & 324.0 & 321.0 & $-1 \%$ \\
\hline $\mathrm{ME}(\mu \mathrm{g} \mathrm{N}$ eq./dose $)$ & 38.1 & 37.4 & $-2 \%$ & 27.6 & 27.4 & $-1 \%$ \\
\hline HTc (mg DB eq./dose) & 107.0 & 104.0 & $-3 \%$ & 32.5 & 32.2 & $-1 \%$ \\
\hline HTnc (mg DB eq./dose) & $2,350.0$ & $2,290.0$ & $-3 \%$ & $1,250.0$ & $1,230.0$ & $-2 \%$ \\
\hline FET (mg DB eq./dose) & 16.7 & 16.3 & $-2 \%$ & 7.8 & 7.7 & $-1 \%$ \\
\hline MET (mg DB eq./dose) & 24.5 & 23.9 & $-2 \%$ & 11.7 & 11.6 & $-1 \%$ \\
\hline TET (g DB eq./dose) & $4,590.0$ & $4,500.0$ & $-2 \%$ & $2,730.0$ & $2,700.0$ & $-1 \%$ \\
\hline OD ( $\mu \mathrm{g}$ CFC-11 eq./dose) & 18.1 & 17.6 & $-3 \%$ & 3.3 & 3.3 & $0 \%$ \\
\hline POFh (mg NOx eq./dose) & 481.0 & 479.0 & $0 \%$ & 569.0 & 567.0 & $0 \%$ \\
\hline POFe (mg NOx eq./dose) & 770.0 & 768.0 & $0 \%$ & 915.0 & 911.0 & $0 \%$ \\
\hline
\end{tabular}

${ }^{\mathrm{a}}$ The negative sign denotes reduction in impacts. For the impacts nomenclature, see Figure 3.

\subsubsection{Uncertainty analysis}

The uncertainty analysis has been carried out to examine the reliability of the results against a likely range of variations in different inventory parameters. These include the quantities of raw materials and energy used in the production of inhaler devices, energy used and emissions during the production of propellants, the quantity of propellants used in pMDIs and the transport of raw materials. Since the data on the variations in the above-mentioned parameters are not available, an arbitrary variation of $\pm 25 \%$ from the base-case values of the parameters has been applied.

A Monte Carlo simulation with 10,000 iterations has been performed to generate probabilistic values for the impacts of all four inhalers considered in the study. The box plots in Figure 7 show the interquartile ranges along with the $10^{\text {th }}$ and $90^{\text {th }}$ percentile ranges. It can be seen that for the pMDIs, the impacts deviate by $\pm 12-22 \%$ relative to the base case. The greatest variation can be observed for GWP for HFC-152a ( $\pm 17 \%)$ and HFC-134a $( \pm 20 \%)$. The other significant deviations $( \pm 22 \%)$ are found for the HT and POF impacts of the DPI. 


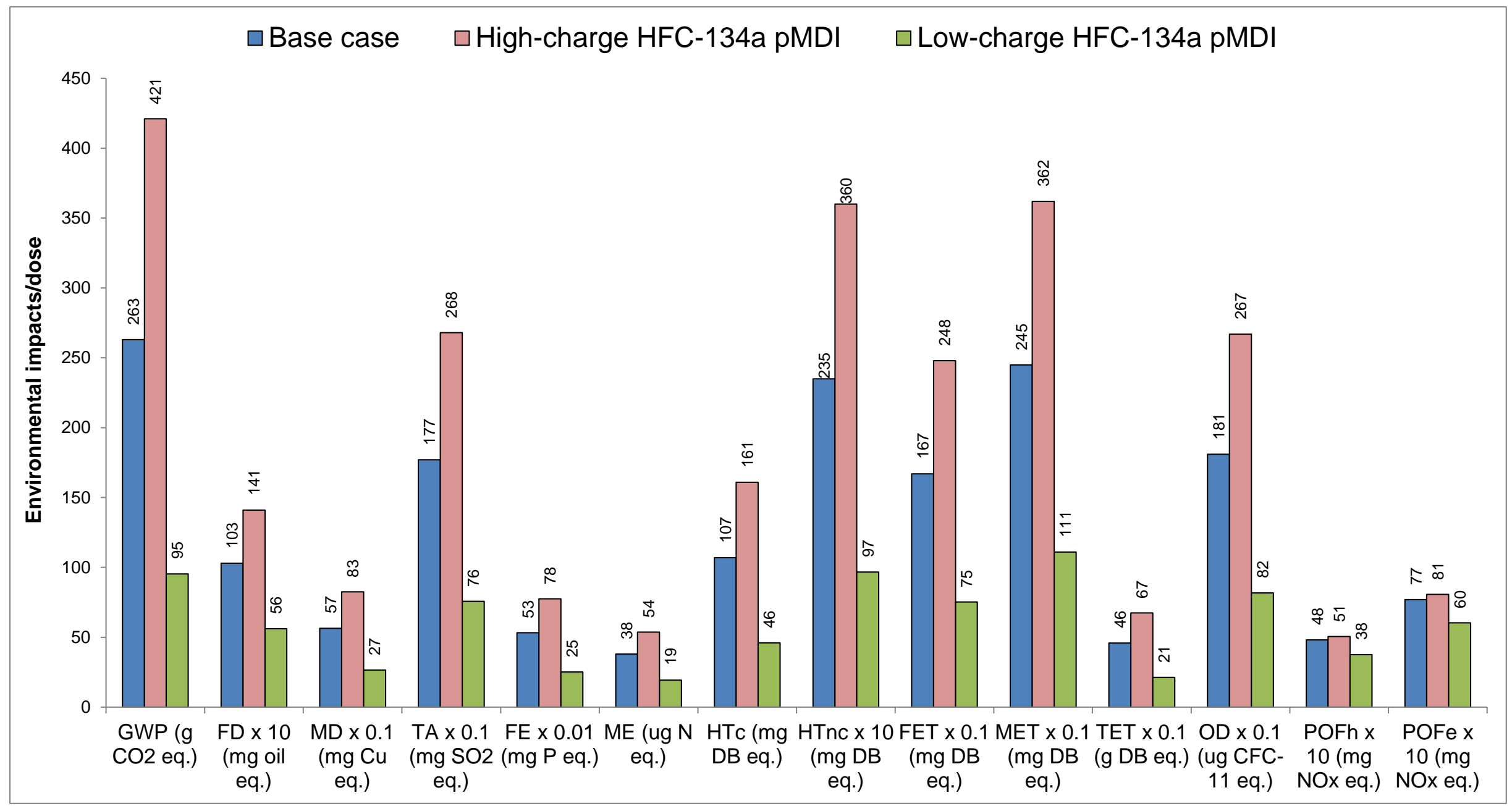

Figure 5 The effect on impacts of the amount of propellant in inhalers

[Some impacts have been scaled to fit. To obtain the original values, multiply by the factor in brackets shown on the $\mathrm{x}$-axis for relevant impacts. For the impacts nomenclature, see Figure 3]. 


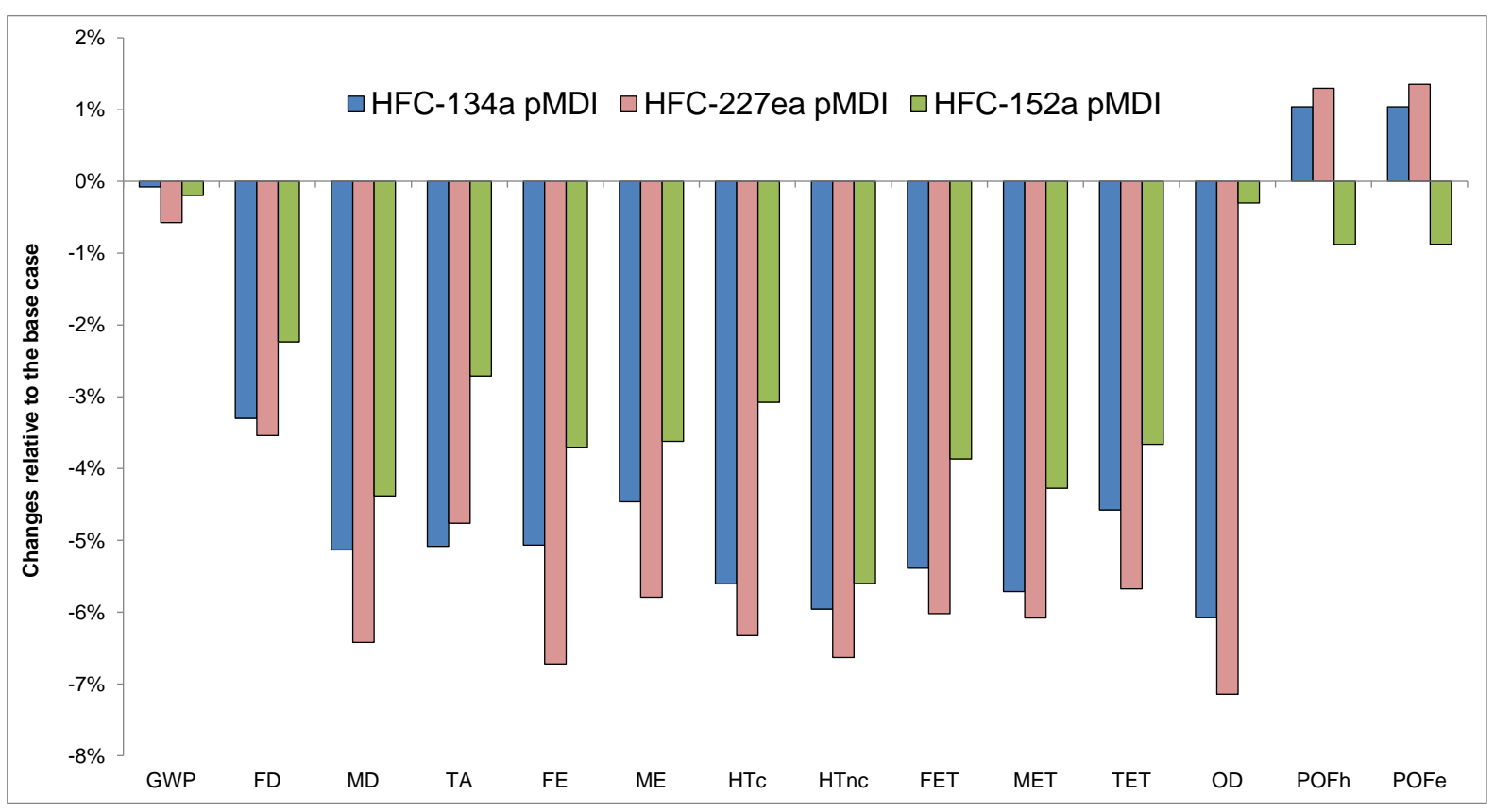

Figure 6 The effect on impacts of using the 'avoided burdens' approach compared to economic allocation

[For the impacts nomenclature, see Figure 3].

Despite these variations in the impacts, the estimated uncertainty ranges (whisker bars in Figure 7) for the HFC-152a inhaler do not overlap with the other three types of inhaler for any of the ten impact categories for which it has lower impacts. This suggests a high confidence in the findings that the HFC-152a inhaler has lower environmental impacts in those ten categories compared to the other inhalers.

\subsubsection{Comparison of results with literature}

To validate the findings, this section compares the results for HFC-134a, HFC-227ea and dry powder inhalers obtained in the current work with other studies. Comparison of the results for HFC-152a pMDI is not possible as this is the first time an LCA study has been carried out for this type of inhaler.

As mentioned in the introduction, three other studies have assessed the GWP of inhalers and their results are summarised in Table 8 . As can be observed from the table, the results of this study are congruent with the UNEP (2014) and GlaxoSmithKline (2014) assessments.

However, the GWP of the HFC-134a inhaler in Goulet et al. (2017) study is much lower. This is because they considered ProVent ${ }^{\circledR}$ inhaler, which uses $60 \%$ less propellant, hence a direct comparison cannot be made. However, the results agree very well with the estimates in the sensitivity analysis for Airomir ${ }^{\circledR}$, a similar type of inhaler (97 vs $95 \mathrm{~g} \mathrm{CO}_{2}$ eq./dose). Therefore, it can be concluded that the impacts estimated here for the existing inhalers fall within the ranges found in the literature. 


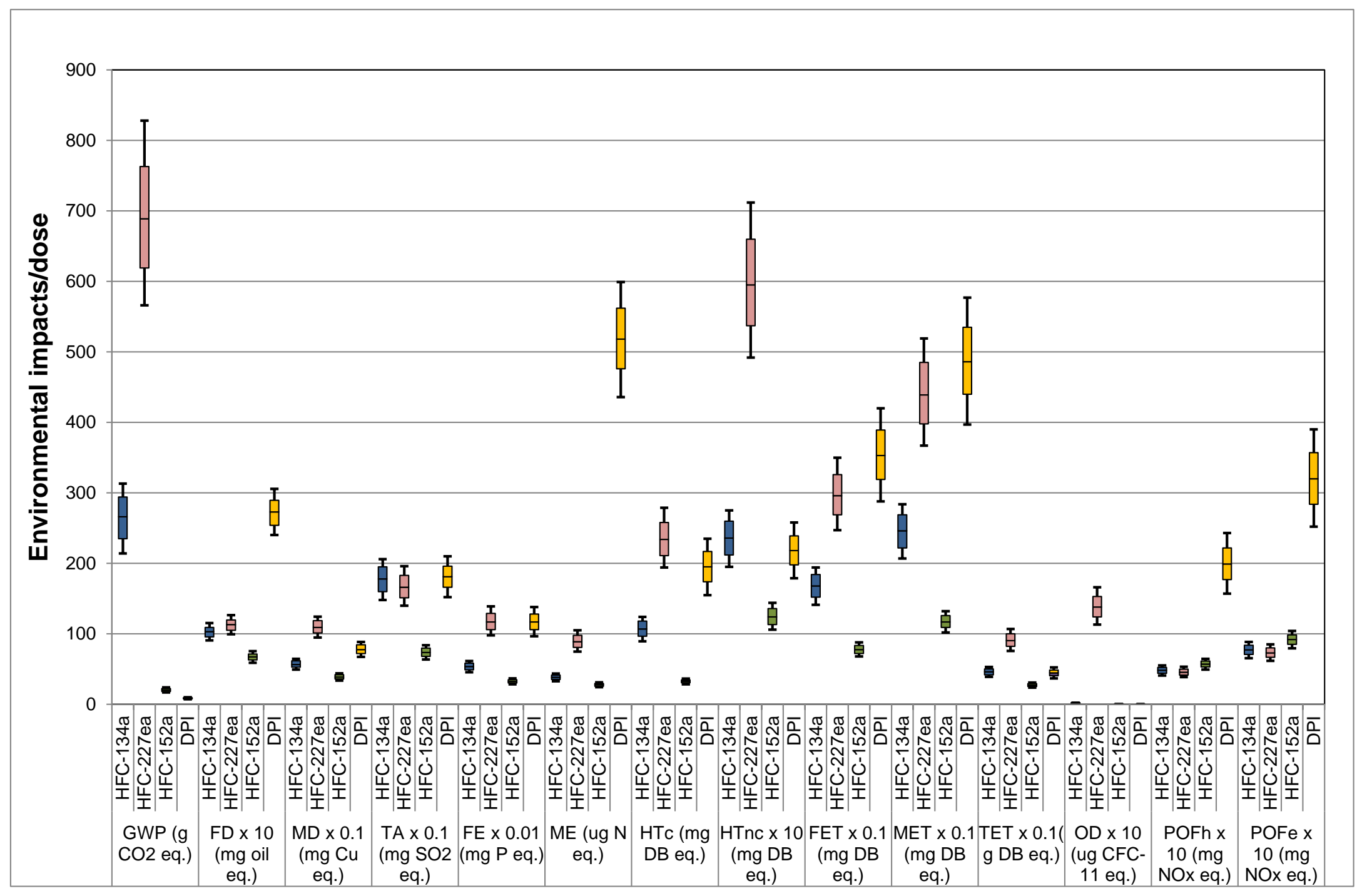

Figure 7 The results of the uncertainty analysis

[Box plots represent the $1^{\text {st }}$ and $3^{\text {rd }}$ quartiles and the whiskers show the range between the $10^{\text {th }}$ and $90^{\text {th }}$ percentile. Some impacts have been scaled to fit. To obtain the original values, multiply by the factor in brackets shown on the x-axis for relevant impacts. For the impacts nomenclature, see Figure 3]. 
Table 8 Comparison of results with literature

\begin{tabular}{|c|c|c|c|c|}
\hline Source & $\begin{array}{l}\text { HFC-134a pMDI } \\
\text { (g CO } \mathrm{CO}_{2} \text { eq./dose) }\end{array}$ & $\begin{array}{l}\text { HFC-227ea pMDI } \\
\text { (g CO } \mathrm{CO}_{2} \text { eq./dose) }\end{array}$ & $\begin{array}{c}\text { DPI } \\
\left(\mathrm{g} \mathrm{CO}_{2} \text { eq./dose) }\right.\end{array}$ & Comments \\
\hline This study & 263 & 697 & 9 & - \\
\hline UNEP (2014) & $200-300$ & $600-800$ & $8-60$ & - \\
\hline $\begin{array}{l}\text { GlaxoSmithKline } \\
(2014)\end{array}$ & $280-340$ & - & 10.4 & $\begin{array}{l}\text { For DPI, the GWP is } 20 \mathrm{~g} \\
\mathrm{CO}_{2} \text { eq./dose, including the } \\
\text { active pharmaceutical } \\
\text { ingredients (API). The } \\
\text { contribution of API to GWP } \\
\text { is } 48 \% \text {. }\end{array}$ \\
\hline $\begin{array}{l}\text { Goulet et al. } \\
(2017)\end{array}$ & 97 & - & - & $\begin{array}{l}\text { ProVent® inhaler with } 6 \mathrm{~g} \\
\text { of propellant for a } 200 \text { - } \\
\text { dose pMDI. }\end{array}$ \\
\hline
\end{tabular}

\subsection{Environmental impacts of inhalers at the UK level}

This section analyses the environmental impacts of inhalers used in the UK based on the results presented in the previous sections and the quantities of the inhalers prescribed annually. The data for the latter were obtained from the NHS in England, Scotland, Wales and $\mathrm{NI}$ (Table 5). As can be seen in Figure 8, the annual GWP of inhalers amounts to 1.34 $\mathrm{Mt} \mathrm{CO}_{2}$ eq. Considering that the total GHG emissions of the NHS in England and Scotland are $26.6 \mathrm{Mt} \mathrm{CO}$ eq./yr (Sustainable Development Unit, 2016) and $2.63 \mathrm{Mt} \mathrm{CO}_{2}$ eq./yr (NHS Scotland, 2009), respectively, the inhalers account for around $4.3 \%$ of the NHS emissions in England and Scotland. The data for GHG emissions for the NHS in Wales and Northern Ireland are not available. The contribution of inhalers to the UK's GHG emissions is around $0.3 \%$. Although this percentage appears to be small, it is equivalent to the annual GHG emissions from 610,000 diesel cars in the $\mathrm{UK}^{2}$. The other environmental impacts cannot be put into context as their data, both at the NHS and UK levels, are not available.

Figure 8 also shows that the HFC-134a inhalers have the highest contribution to all impact categories, except ME and OD. These two impacts are respectively mainly due to DPIs $(60 \%)$ and HFC-227ea and HFC-134a (50\% each).

To identify opportunities for reducing the impacts associated with the annual usage of inhalers, the following seven possible future scenarios are considered:

- S-1: Replacement of both HFC-134a and HFC-227ea with HFC-152a pMDIs

- S-2: Replacement of all pMDIs with DPIs

- S-3: Reduction in propellant usage in pMDIs by $60 \%$ (as in some current inhalers)

- S-4: Recovery of propellants from used pMDIs

- S-5: Combination of S-1, S-3 and S-4 (replacement of both HFC-134a and HFC-227ea in pMDI by HFC-152a, reduction in propellant usage in pMDI by $60 \%$ and recovery of HFC152a from used pMDIs)

- S-6: Use of HFC-134a in all pMDIs (replacement of HFC-227ea with HFC-134a pMDIs)

- S-7: Combination of S-3, S-4 and S-6 (all pMDIs with HFC-134a, reduction in propellant usage in pMDI by $60 \%$ and recovery of HFC-134a from used pMDIs).

\footnotetext{
${ }^{2}$ GHG emissions from an average diesel car: $177.5 \mathrm{~g} \mathrm{CO}_{2}$ eq./km (DEFRA, 2018); annual mileage per car: 12,400 km (Department for Transport, 2018).
} 


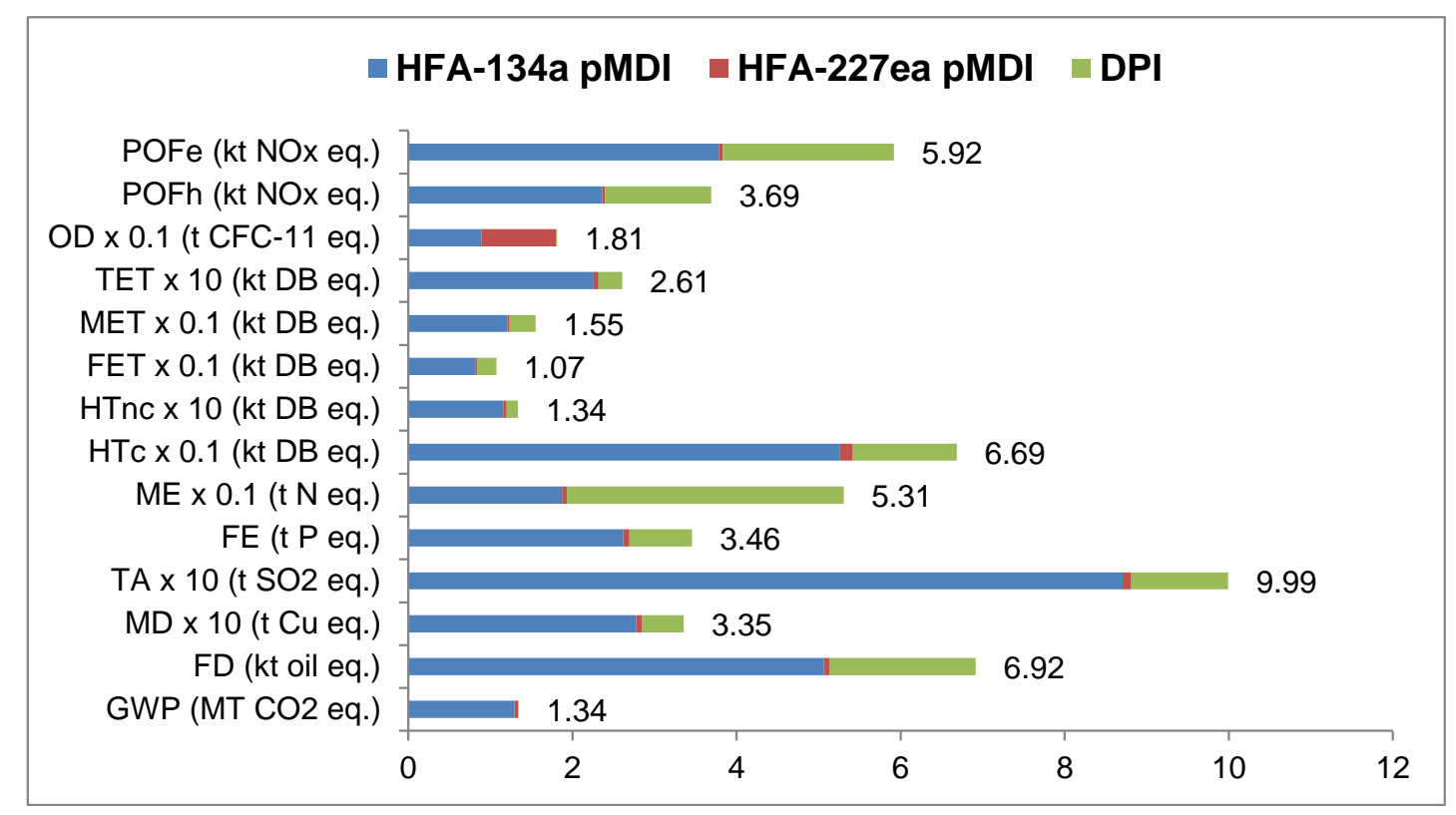

Figure 8 Environmental impacts of the annual usage of inhalers in the UK

[All impacts are expressed per year. Some impacts have been scaled to fit. To obtain the original values, multiply by the factor in brackets shown on the x-axis for relevant impacts. For the impacts nomenclature, see Figure 3].

The results in Table 9 suggest that by replacing current propellants in pMDI with HFC-152a (S-1), the GWP and OD would be reduced by $90 \%-92 \%$. This would also lead to large reductions $(>40 \%)$ in acidification, ecotoxicity and human toxicity impacts; the other impacts would be $10 \%-37 \%$ lower. The only exceptions are the POF impacts which would increase in this scenario by $12 \%$.

Replacing all pMDIs with DPIs (S-2) would achieve even higher reductions (94-96\%) for GWP and OD than in S-1. However, this would happen at the expense of several other impacts which would increase significantly. The most notable increases would be for ME, POF and FD, which would be 2-6 times higher than currently.

Using $60 \%$ less propellant per dose (S-3) would result in a $59 \%$ and $56 \%$ reduction in GWP and OD, respectively (Table 9). All other impacts would also be reduced, ranging from $18 \%$ for ME to $50 \%$ for HT (non-cancer).

It is estimated that about $10 \%$ of propellant is left in used pMDIs (Enviros March, 2000), which can be recovered and reused in refrigeration or other industries. GSK has set up a scheme called "Complete the Cycle" in the UK in 2011 to recover the remaining propellant from used inhalers (GlaxoSmithKline, 2011). Therefore, it is assumed in S-4, that in the future all used pMDIs will be collected and the leftover propellants will be treated and reused in industrial applications. It is also assumed that plastic and aluminium components of pMDI are recycled. This would result in the reduction of all impacts compared to the base case; however, the reductions would be relatively small. The most notable reductions are found for GWP, FD and MD, which would be reduced by $10-15 \%$. The reductions in the other impacts would be smaller (3\%-8\%).

As shown in Table 9, combining S-1, S-3 and S-4 in S-5 would reduce all the impacts by $12 \%$ (POF) to $97 \%$ (GWP). For the latter, the annual GHG savings would be equivalent to taking 590,000 diesel cars off the road. Furthermore, replacing all HFC-227ea with HFC134 a inhalers (S-6) would result in a very small reduction $(\leq 2 \%)$ in all impacts except OD, which would be reduced by $50 \%$ (Table 9 ). In scenario S-7, which combines S-3, S-4 and S6 , the highest reduction also occurs for OD (75\%). This is followed by GWP and MD which 
are reduced by $64 \%$ and $54 \%$, respectively. The reductions in other impacts vary from $13 \%$ for ME to $49 \%$ for HT (non-cancer).

Table 9 Comparison of different scenarios with the current situation ${ }^{a}$

\begin{tabular}{|c|c|c|c|c|c|c|c|}
\hline & S-1 & S-2 & S-3 & S-4 & S-5 & S-6 & S-7 \\
\hline Global warming potential & $-92 \%$ & $-96 \%$ & $-59 \%$ & $-10 \%$ & $-97 \%$ & $-2 \%$ & $-64 \%$ \\
\hline Fossil depletion & $-26 \%$ & $122 \%$ & $-34 \%$ & $-13 \%$ & $-51 \%$ & $0 \%$ & $-41 \%$ \\
\hline Metal depletion & $-27 \%$ & $30 \%$ & $-44 \%$ & $-15 \%$ & $-64 \%$ & $-1 \%$ & $-54 \%$ \\
\hline Terrestrial acidification & $-51 \%$ & $2 \%$ & $-48 \%$ & $-4 \%$ & $-67 \%$ & $0 \%$ & $-48 \%$ \\
\hline Freshwater eutrophication & $-31 \%$ & $91 \%$ & $-40 \%$ & $-5 \%$ & $-52 \%$ & $-1 \%$ & $-40 \%$ \\
\hline Marine eutrophication & $-10 \%$ & $450 \%$ & $-18 \%$ & $3 \%$ & $-16 \%$ & $-1 \%$ & $-13 \%$ \\
\hline Human toxicity (cancer) & $-57 \%$ & $64 \%$ & $-45 \%$ & $-8 \%$ & $-69 \%$ & $-1 \%$ & $-48 \%$ \\
\hline Human toxicity (non-cancer) & $-43 \%$ & $-8 \%$ & $-50 \%$ & $-3 \%$ & $-65 \%$ & $-2 \%$ & $-49 \%$ \\
\hline Freshwater ecotoxicity & $-42 \%$ & $86 \%$ & $-42 \%$ & $2 \%$ & $-51 \%$ & $-1 \%$ & $-35 \%$ \\
\hline Marine ecotoxicity & $-42 \%$ & $77 \%$ & $-42 \%$ & $2 \%$ & $-51 \%$ & $-1 \%$ & $-35 \%$ \\
\hline Terrestrial ecotoxicity & $-37 \%$ & $-4 \%$ & $-47 \%$ & $-4 \%$ & $-59 \%$ & $-1 \%$ & $-45 \%$ \\
\hline Ozone depletion & $-90 \%$ & $-94 \%$ & $-56 \%$ & $-6 \%$ & $-90 \%$ & $-50 \%$ & $-75 \%$ \\
\hline $\begin{array}{l}\text { Photochemical oxidants formation } \\
\text { (human health) }\end{array}$ & $12 \%$ & $204 \%$ & $-19 \%$ & $-8 \%$ & $-12 \%$ & $0 \%$ & $-17 \%$ \\
\hline $\begin{array}{l}\text { Photochemical oxidants formation } \\
\text { (ecosystems) }\end{array}$ & $12 \%$ & $205 \%$ & $-18 \%$ & $-8 \%$ & $-12 \%$ & $0 \%$ & $-17 \%$ \\
\hline
\end{tabular}

${ }^{a}$ The negative sign denotes reduction in impacts.

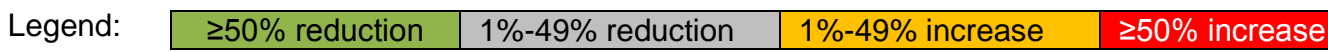

\section{Conclusions}

This study has evaluated the life cycle environmental impacts associated with pMDI and DPI, two most common types of inhaler globally. Three different propellants have been considered for the pMDIs: two used at present (HFC-134a and HFC-227ea) and one currently under consideration by the pharma industry (HFC-152a). The results suggest that pMDIs with HFC-152a have the lowest impacts for ten out of 14 categories considered. DPIs are the best option for GWP and OD while HFC-134a and HFC-227ea have the smallest POF impacts. However, the DPIs are the worst option for eight impacts, followed by the HFC-227ea pMDIs with six highest impacts. The results of the uncertainty analysis show that these findings are robust over the broad range of the influencing parameters.

The annual use of inhalers in the UK generates GHG emissions equivalent to $1.34 \mathrm{Mt} \mathrm{CO}_{2}$ eq., largely due to the HFC-134a inhalers. This represents $4.3 \%$ of the NHS and $0.3 \%$ of national emissions. The results of the scenario analysis show that replacing HFC-227ea and HFC-134a propellants by HFC-152a in pMDIs would result in a 92\% reduction in GWP and OD. Most other impacts would also decrease significantly. However, the successful deployment of HFC-152a propellants in pMDls will depend on safety and formulation behaviour, which are still being investigated.

Although DPI considered in this study has the lowest GWP and OD, switching from pMDIs to DPIs could cause a significant increase in several other impacts, including human toxicity, marine eutrophication and fossil depletion. Moreover, it is not yet technically or economically feasible to replace completely HFC-based pMDIs, due to cost, technical and patientacceptability factors. Since replacing propellants or pMDls requires further research and development, pharmaceutical companies should consider these measures as part of a longterm strategy. In the short-term, they should implement already tried and tested measures for minimising propellant emissions, including reducing the size of metering valves to reduce propellant usage per dose and increasing propellant recovery for spent or partly-used pMDIs. Such actions will continue to be beneficial should HFC-152a be introduced on a commercial basis in the future. 


\section{Acknowledgements}

The authors would like to acknowledge Dr Stuart Corr and Gary Lloyd (Mexichem) for providing data for the manufacturing processes for HFC-134a and HFC-152a and to Mexichem UK Ltd for financial support.

\section{References}

Amado Alviz, P.L., Alvarez, A.J., 2017. Comparative life cycle assessment of the use of an ionic liquid ([Bmim] $\mathrm{Br})$ versus a volatile organic solvent in the production of acetylsalicylic acid. Journal of Cleaner Production 168, 1614-1624.

Banks, R.E., Clarke, E.K., Johnson, E.P., Sharratt, P.N., 1998. Environmental aspects of fluorinated materials: Part 31: Comparative life cycle assessment of the impacts associated with fire extinguishants HFC-227ea and IG-541. Process Safety and Environmental Protection 76(3), 229-238.

Baron, M., 2012. Towards a Greener Pharmacy by More Eco Design. Waste and Biomass Valorization 3(4), 395-407.

Brunet, R., Guillén-Gosálbez, G., Jiménez, L., 2014. Combined simulation-optimization methodology to reduce the environmental impact of pharmaceutical processes: application to the production of Penicillin V. Journal of Cleaner Production 76, 55-63.

Cespi, D., Beach, E.S., Swarr, T.E., Passarini, F., Vassura, I., Dunn, P.J., Anastas, P.T., 2015. Life cycle inventory improvement in the pharmaceutical sector: assessment of the sustainability combining PMI and LCA tools. Green Chemistry 17(6), 3390-3400.

Chaturvedi, U., Sharma, M., Dangayach, G.S., Sarkar, P., 2017. Evolution and adoption of sustainable practices in the pharmaceutical industry: An overview with an Indian perspective. Journal of Cleaner Production 168, 1358-1369.

Cue, B.W., Zhang, J., 2009. Green process chemistry in the pharmaceutical industry. Green Chemistry Letters and Reviews 2(4), 193-211.

De Soete, W., Jiménez-González, C., Dahlin, P., Dewulf, J., 2017. Challenges and recommendations for environmental sustainability assessments of pharmaceutical products in the healthcare sector. Green Chemistry 19(15), 3493-3509.

DEFRA, 2018. UK Government GHG Conversion Factors for Company Reporting. https://www.gov.uk/government/publications/greenhouse-gas-reporting-conversionfactors-2018.

Department for Transport, 2018. Vehicle mileage and occupancy. https://www.gov.uk/government/statistical-data-sets/nts09-vehicle-mileage-andoccupancy\#car-mileage.

EC, 2018. Eurostat - Waste database - MSW treatment in the UK for 2016. http://ec.europa.eu/eurostat/web/environment/waste/database.

Eckelman, M.J., Sherman, J., 2016. Environmental impacts of the U.S. health care system and effects on public health. PLOS ONE 11(6), e0157014.

Eckelman, M.J., Sherman, J.D., MacNeill, A.J., 2018. Life cycle environmental emissions and health damages from the Canadian healthcare system: An economicenvironmental-epidemiological analysis. PLOS Medicine 15(7), e1002623.

Ecoinvent, 2016. Ecoinvent v3.3 database. Swiss Centre for Life Cycle Inventories, Dübendorf, Switzerland.

Enviros March, 2000. Study on the use of HFCs for metered dose inhalers in the European Union.

http://ec.europa.eu/DocsRoom/documents/12171/attachments/1/translations/en/renditi ons/native.

Ferguson, G.T., Hickey, A.J., Dwivedi, S., 2018. Co-suspension delivery technology in pressurized metered-dose inhalers for multi-drug dosing in the treatment of respiratory diseases. Respiratory Medicine 134, 16-23. 
GlaxoSmithKline, 2009. Highlights of prescribing information - Ventolin HFA $®($ albuterol sulfate) inhalation aerosol. https://www.accessdata.fda.gov/drugsatfda docs/label/2014/020983s032lbl.pdf.

GlaxoSmithKline, 2011. Complete the cycle. http://uk.gsk.com/en-gb/responsibility/ourplanet/complete-the-cycle/.

GlaxoSmithKline, 2014. Product carbon footprint certification summary report. https://networks.sustainablehealthcare.org.uk/sites/default/files/media/GSK\%20Carbon \%20Trust\%20Certification\%202014.pdf.

Goulet, B., Olson, L., Mayer, B., 2017. A comparative life cycle assessment between a metered dose inhaler and electric nebulizer. Sustainability 9(10), 1725.

Huijbregts, M.A.J., Z.J.N.Steinmann, Elshout, P.M.F., Stam, G., Verones, F., Vieira, M.D.M., Hollander, A., Zijp, M., Zelm, R.V., 2017. ReCiPe 2016 v1.1 A harmonized life cycle impact assessment method at midpoint and endpoint level; report I: Characterisation. https://www.rivm.nl/en/Topics/L/Life Cycle Assessment LCA/Downloads/Documents ReCiPe2017/Report ReCiPe Update 2017.pdf.

ISO, 2006a. ISO 14040: Environmental management - Life cycle assessment - Principles and framework. Geneva, Switzerland.

ISO, 2006b. ISO 14044: Environmental Management - Life cycle assessment Requirements and guidelines. Geneva, Switzerland.

Jiménez-González, C., Poechlauer, P., Broxterman, Q.B., Yang, B.-S., am Ende, D., Baird, J., Bertsch, C., Hannah, R.E., Dell'Orco, P., Noorman, H., Yee, S., Reintjens, R., Wells, A., Massonneau, V., Manley, J., 2011. Key Green Engineering Research Areas for Sustainable Manufacturing: A Perspective from Pharmaceutical and Fine Chemicals Manufacturers. Organic Process Research \& Development 15(4), 900-911.

Kou, X., Cao, X., 2016. Review of dry powder inhaler devices. American Pharmaceutical Review.

Leone, F., Gignone, A., Ronchetti, S., Cavalli, R., Manna, L., Banchero, M., Onida, B., 2018. A green organic-solvent-free route to prepare nanostructured zinc oxide carriers of clotrimazole for pharmaceutical applications. Journal of Cleaner Production 172, 14331439.

Malik, A., Lenzen, M., McAlister, S., McGain, F., 2018. The carbon footprint of Australian health care. The Lancet Planetary Health 2(1), e27-e35.

McAlister, S., Ou, Y., Neff, E., Hapgood, K., Story, D., Mealey, P., McGain, F., 2016. The Environmental footprint of morphine: a life cycle assessment from opium poppy farming to the packaged drug. BMJ Open 6(10), e013302.

Müller, G., Sugiyama, H., Stocker, S., Schmidt, R., 2014. Reducing Energy Consumption in Pharmaceutical Production Processes: Framework and Case Study. Journal of Pharmaceutical Innovation 9(3), 212-226.

Myhre, G., D. Shindell, F.-M. Bréon, W. Collins, J. Fuglestvedt, J. Huang, D. Koch, J.-F. Lamarque, D. Lee, B. Mendoza, T. Nakajima, A. Robock, G. Stephens, T. Takemura and $H$. Zhang, 2013. Anthropogenic and natural radiative forcing, in: Stocker, T.F., D. Qin, G.-K. Plattner, M. Tignor, S.K. Allen, J. Boschung, A. Nauels, Y. Xia, V. Bex and P.M. Midgley (Ed.) Climate Change 2013: The Physical Science Basis. Contribution of Working Group I to the Fifth Assessment Report of the Intergovernmental Panel on Climate Change. Cambridge University Press, Cambridge, United Kingdom and New York, NY, US.

Myrdal, P.B., Sheth, P., Stein, S.W., 2014. Advances in metered dose inhaler technology: Formulation development. AAPS PharmSciTech 15(2), 434-455.

NAEI, 2018. England's GHG inventory by source for 2015. National Atmospheric Emissions Inventory, http://naei.beis.gov.uk/data/.

NHS England, 2017. Prescription cost analysis - England 2016. https://digital.nhs.uk/dataand-information/publications/statistical/prescription-cost-analysis/prescription-costanalysis-england-2016.

NHS Northern Ireland, 2017. Prescription cost analysis - Northern Ireland 2016. http://www.hscbusiness.hscni.net/services/1806.htm. 
NHS Scotland, 2009. Carbon footprint of NHS Scotland (1990-2004). http://www.hfs.scot.nhs.uk/downloads/1256227209-NHS Scotland CF report-

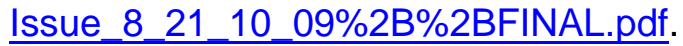

NHS Scotland, 2017. Prescription cost analysis for financial year 2015/16. http://www.isdscotland.org/Health-topics/Prescribing-and-medicines/CommunityDispensing/Prescription-Cost-Analysis/.

NHS Wales, 2017. Prescription cost analysis: Wales 2016. http://www.primarycareservices.wales.nhs.uk/prescription-cost-analysis.

Noakes, T., Corr, S., 2016. The future of Propellants for pMDIs, Drug Delivery to the Lungs 27, . The Aerosol Society, Bristol, UK, pp. 61-64.

Parvatker, A.G., Tunceroglu, H., Sherman, J.D., Coish, P., Anastas, P., Zimmerman, J.B., Eckelman, M.J., 2019. Cradle-to-Gate Greenhouse Gas Emissions for Twenty Anesthetic Active Pharmaceutical Ingredients Based on Process Scale-Up and Process Design Calculations. ACS Sustainable Chemistry \& Engineering.

Ponder, C., Overcash, M., 2010. Cradle-to-gate life cycle inventory of vancomycin hydrochloride. Science of The Total Environment 408(6), 1331-1337.

Stein, S.W., Thiel, C.G., 2017. The History of therapeutic aerosols: A chronological review. Journal of Aerosol Medicine and Pulmonary Drug Delivery 30(1), 20-41.

Sustainable Development Unit, 2016. Carbon update for the health and care sector in England 2015. www.sduhealth.org.uk/report.

Thinkstep, 2018. GaBi ts V 8 software and database. https://www.thinkstep.com/.

UNEP, 1987. The Montreal Protocol on substances that deplete the ozone layer.

UNEP, 2014. Report of the Medical Technical Options Committee (MTOC) 2014 assessment report, UNEP Ozone Secretariat. United Nations Environment Programme, http://ozone.unep.org/Assessment Panels/TEAP/Reports/MTOC/MTOC-AssessmentReport-2014.pdf.

UNEP, 2016. Chapter 8: Update on alternatives and BAU scenarios for 2015-2050: MDIs and Aerosols, Report of the Technology and Economic Assessment Panel, September 2016. United Nations Environment Programme, http://ozone.unep.org/en/assessmentpanels/technology-and-economic-assessment-panel.

Wernet, G., Conradt, S., Isenring, H.P., Jiménez-González, C., Hungerbühler, K., 2010. Life cycle assessment of fine chemical production: a case study of pharmaceutical synthesis. The International Journal of Life Cycle Assessment 15(3), 294-303. 


\section{Design and environmental sustainability assessment of small-scale off-grid energy systems for remote rural communities}

Jhud Mikhail Aberilla, Alejandro Gallego-Schmid, Laurence Stamford, Adisa Azapagic

\section{Supporting Information}

Table S1. Raw materials processing and assembly data for $1 \mathrm{~kg}$ lead acid battery [1]

\begin{tabular}{lr}
\hline Life cycle stage & Amount \\
\hline Raw materials/components & 0.71 \\
Lead (kg) & \\
Cathode alloying additives & 0.0001 \\
Aluminium, wrought alloy (kg) & 0.0003 \\
Calcium carbide, technical grade (kg) & 0.0001 \\
Silver (kg) & 0.004 \\
Tin (kg) & \\
Anode additives & 0.0012 \\
Barite (kg) & 0.0004 \\
Carbon black (kg) & 0.0005 \\
Sulphate pulp (kg) & \\
Electrolyte & 0.063 \\
Sulfuric acid (kg) & 0.108 \\
Water, deionised, from tap water, at user (kg) & 0.025 \\
Separator, glass fibre (kg) & \\
Electronics & 0.005 \\
Copper (kg) & $2.00 \mathrm{E}-06$ \\
Integrated circuit, logic type (kg) & 0.00013 \\
Printed wiring board (kg) & \\
Casing & 0.0076 \\
Acryloni trile-butadiene-styrene copolymer (kg) & 0.075 \\
Polypropylene, granulate (kg) & \\
Assembly & 4.59 \\
Electricity, medium voltage (MJ) & 6.31 \\
Heat, district or industrial, natural gas (MJ) & 0.65 \\
Heat, heavy fuel oil, at industrial furnace (MJ) & \\
\hline
\end{tabular}

Table S2. Raw materials processing and assembly data for $1 \mathrm{~kg}$ Li-ion battery [2]

\begin{tabular}{lr}
\hline Life cycle stage & Amount \\
\hline Raw materials/components & \\
Cathode, LiMn2O4, for lithium-ion battery $(\mathrm{kg})$ & 0.261 \\
Anode, graphite, for lithium-ion battery $(\mathrm{kg})$ & 0.321 \\
Electrolyte & \\
Ethylene carbonate $(\mathrm{kg})$ & 0.128 \\
Lithium hexafluorophosphate $(\mathrm{kg})$ & 0.015 \\
Battery separator (kg) & 0.043 \\
Electronics & \\
Cable, data cable in infrastructure (m) & 0.373 \\
Cable, three-conductor cable (m) & 0.025 \\
Printed wiring board (kg) & 0.003 \\
Casing & \\
Aluminium, wrought alloy (kg) & 0.013 \\
Extrusion, plastic film (kg) & 0.059 \\
Polyethylene, low density (kg) & 0.059 \\
Reinforcing steel (kg) & 0.145 \\
Sheet rolling, aluminium (kg) & 0.013 \\
Sheet rolling, steel (kg) & 0.145 \\
Assembly & 0.387 \\
Electricity, low voltage (MJ) & 0.304 \\
Electricity, medium voltage (MJ) & $3.20 \times 10^{-10}$ \\
Chemical factory, organics (units) & $4.58 \times 10^{-10}$ \\
Metal working factory (units) & \\
\hline
\end{tabular}


Table S3. Raw materials processing data for a $2.5-\mathrm{kW}$ converter [3]

\begin{tabular}{lr}
\hline Life cycle stage & Amount \\
\hline Raw materials/components & 1.4 \\
Aluminium, cast alloy (kg) & 0.62 \\
Capacitor (kg) & 5.51 \\
Copper (kg) & 2.5 \\
Corrugated board box (kg) & 0.047 \\
Diode, glass (kg) & 0.237 \\
Electric connector, wire clamp (kg) & 0.06 \\
Fleece, polyethylene (kg) & 0.351 \\
Inductor, ring core choke type (kg) & 0.028 \\
Integrated circuit, logic type (kg) & $8.97 \mathrm{E}-09$ \\
Metal working factory (units) & 0.3 \\
Polystyrene foam slab (kg) & 0.00111 \\
Polyvinylchloride (kg) & 0.2246 \\
Printed wiring board (sqm) & 0.005 \\
Resistor (kg) & 1.4 \\
Section bar extrusion, aluminium (kg) & 9.8 \\
Sheet rolling, steel (kg) & 9.8 \\
Steel, low-alloyed, hot rolled (kg) & 0.01 \\
Styrene-acrylonitrile copolymer (kg) & 0.038 \\
Transistor, wired (kg) & 5.51 \\
Wire drawing, copper (kg) & \\
\hline
\end{tabular}

Table S4. Raw materials processing and assembly and installation data for $1 \mathrm{~km}$ distribution network [4]

\begin{tabular}{lr}
\hline Life cycle stage & Amount \\
\hline Raw materials/components & 0.0557 \\
Building, hall, steel construction (sqm) & 2.17 \\
Building, multi-storey $\left(\mathrm{m}^{3}\right)$ & 1.40 \\
Concrete, normal $\left(\mathrm{m}^{3}\right)$ & 1880 \\
Copper $(\mathrm{kg})$ & 225 \\
Lead $(\mathrm{kg})$ & 237 \\
Light fuel oil $(\mathrm{kg})$ & 75.03 \\
Packaging film, low density polyethylene $(\mathrm{kg})$ & 79.12 \\
Polyvinylchloride, emulsion polymerised $(\mathrm{kg})$ & 540.64 \\
Polyvinylchloride, suspension polymerised $(\mathrm{kg})$ & 1.92 \\
Sawlog and veneer log (m $\left.{ }^{3}\right)$ & 2300 \\
Steel, unalloyed (kg) & 0.087 \\
Sulphur hexafluoride, liquid $(\mathrm{kg})$ & 34.20 \\
Wood preservation (kg) & $3.90 \times 10^{-1}$ \\
Assembly and installation & 40.4 \\
Diesel, burned in building machine $(\mathrm{MJ})$ & \\
Excavation, hydraulic digger $\left(\mathrm{m}^{3}\right)$ &
\end{tabular}


Table S5. Performance specifications of system components

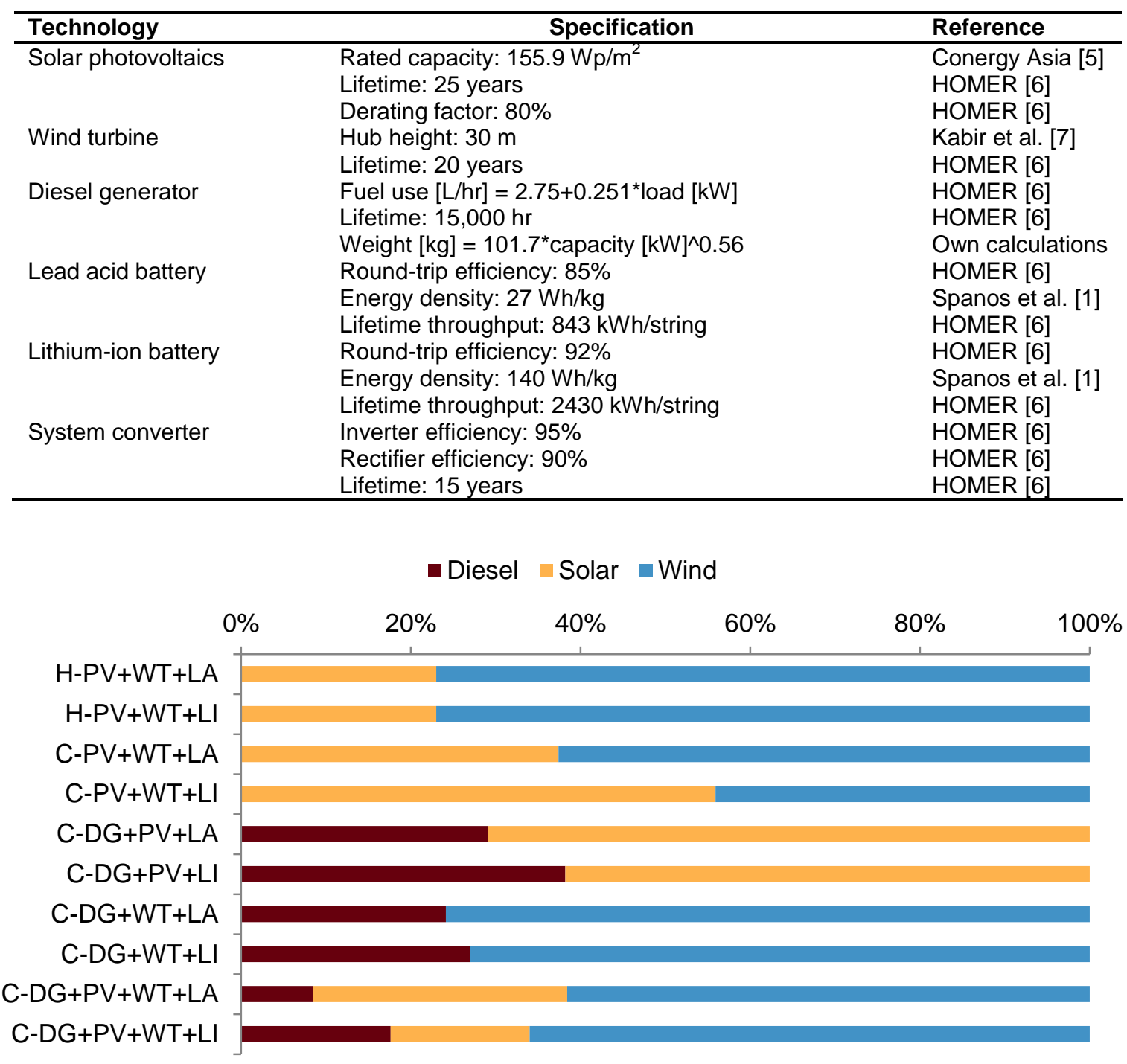

Figure S1. Contribution of different energy sources to the power supply by different hybrid energy systems 
$\square$ PV panel production $\square$ Mounting frame production $\square$ Electric components production $\square$ Transport, installation and operation $\square$ End-of-life

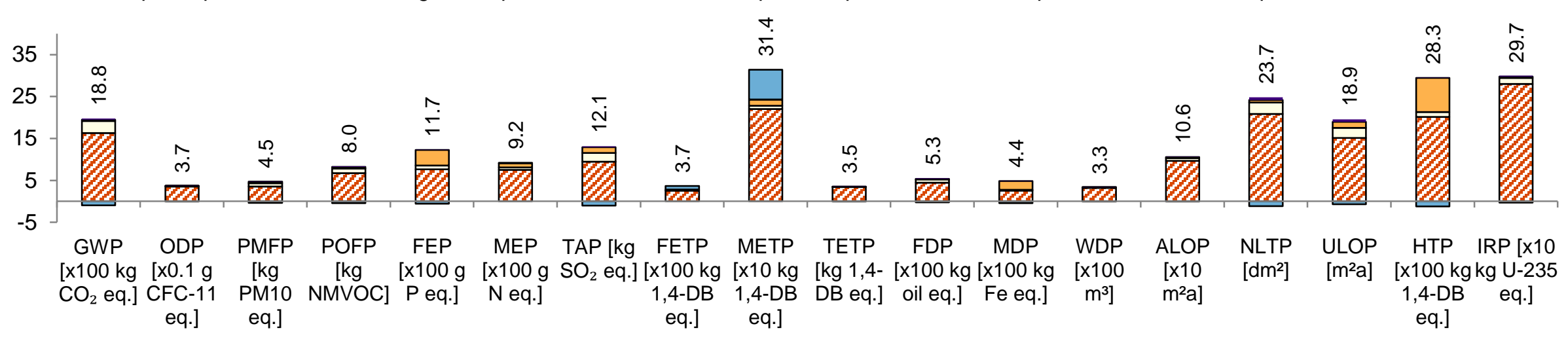

Figure S2. Life cycle environmental impacts of a household-scale solar PV system without storage

[Impacts expressed per kWp capacity. Some impacts have been scaled to fit; to obtain the original values, multiply by the factors given on the $\mathrm{x}$-axis in brackets. ALOP: agricultural land occupation potential; FDP: fossil depletion potential; FETP: freshwater ecotoxicity potential; FEP: freshwater eutrophication potential; GWP: global warming potential; HTP:

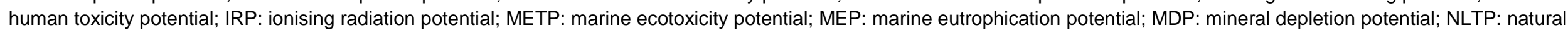
land transformation potential; ODP: ozone depletion potential; PMFP: particulate matter formation potential; POFP: photochemical oxidants formation potential; TAP: terrestrial acidification potential; TETP: terrestrial ecotoxicity potential; ULOP: urban land occupation potential; WDP: water depletion potential]

๑Production, fixed parts $\quad \square$ Production, moving parts

- Transport, installation and operation

$\square$ End-of-life

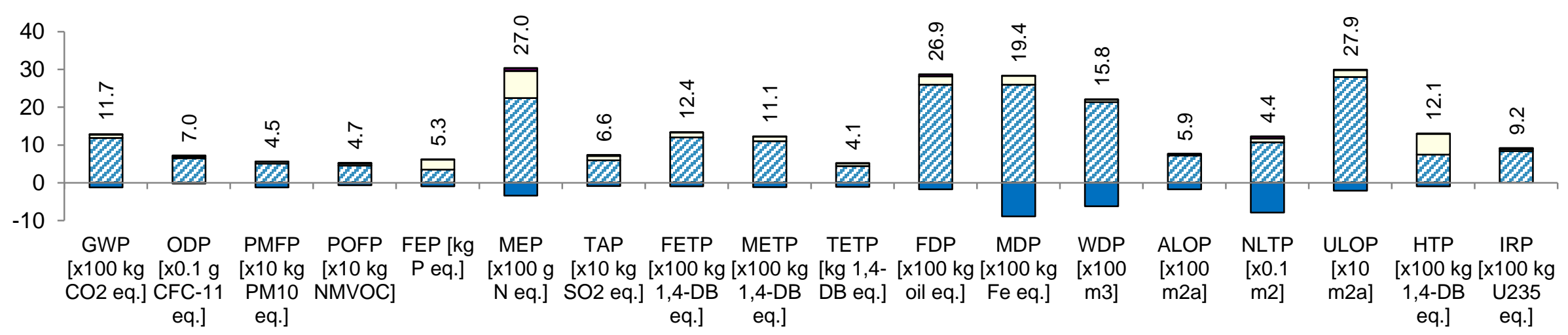

Figure S3. Life cycle environmental impacts of a household-scale wind power system without storage

[Impacts expressed per 5-kW wind turbine. Some impacts have been scaled to fit; to obtain the original values, multiply by the factors given on the $\mathrm{x}$-axis in brackets. For impact acronyms, see Figure S2] 

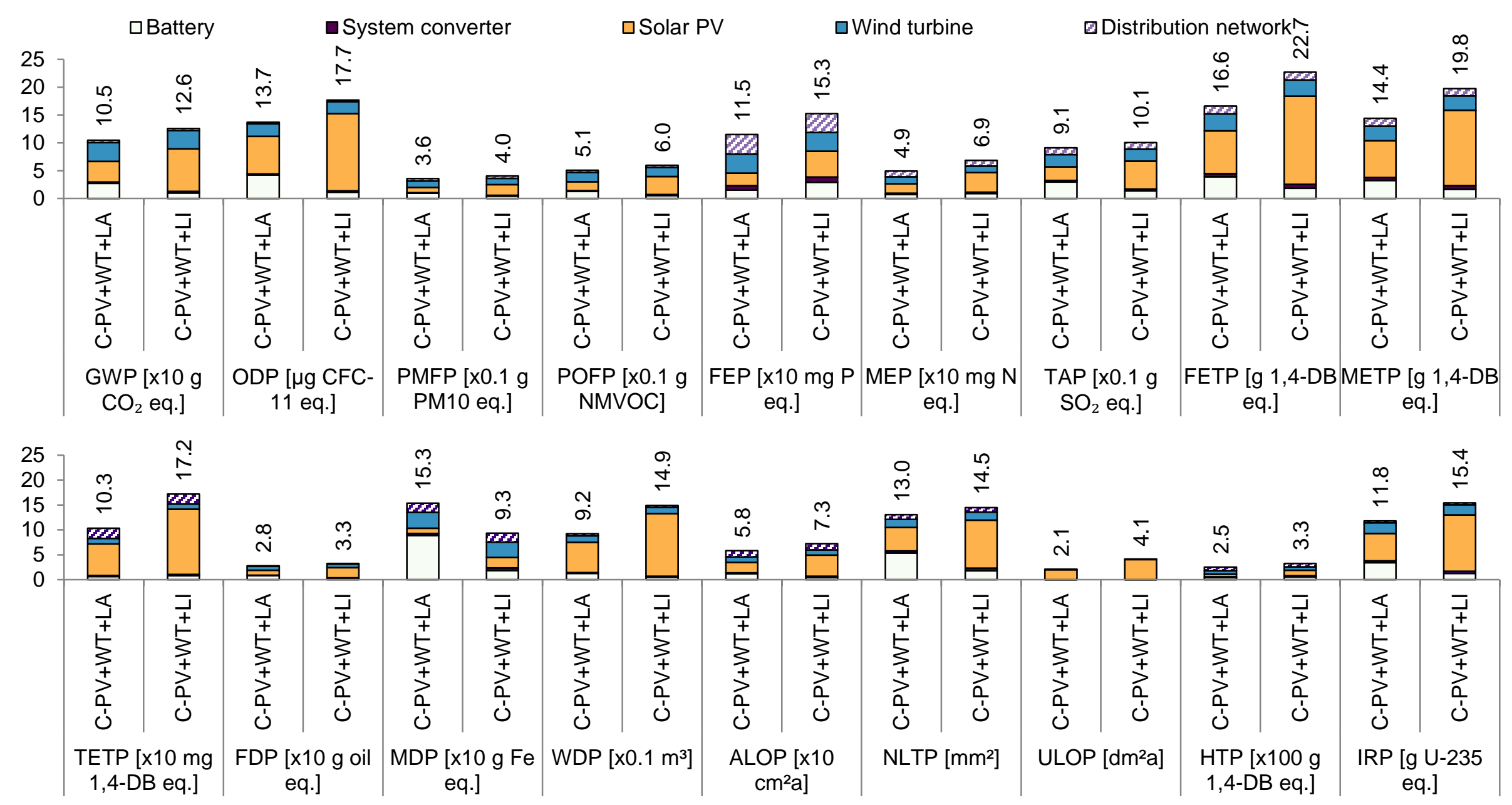

Figure S4. Contribution analysis for community-scale hybrid micro-grid options.

[Impacts expressed per kWh of electricity supplied. Basis: see Table 8 in the paper. Some impacts have been scaled to fit; to obtain the original values, multiply by the factors given on the x-axis in brackets. DG: diesel generator; PV: solar photovoltaics; WT: wind turbine; LA: lead acid; LI: Li-ion. For nomenclature of system types and impact categories, see Figure S2 above and Table 8 in the paper] 


\section{References}

[1] Spanos C, Turney DE, Fthenakis V. Life-cycle analysis of flow-assisted nickel zinc-, manganese dioxide-, and valve-regulated lead-acid batteries designed for demand-charge reduction. Renew Sustain Energy Rev 2015;43:478-94. doi:10.1016/j.rser.2014.10.072.

[2] Notter DA, Gauch M, Widmer R, Wäger P, Stamp A, Zah R, et al. Contribution of Li-lon Batteries to the Environmental Impact of Electric Vehicles. Environ Sci Technol 2010;44:65506. doi:10.1021/es903729a.

[3] Jungbluth N, Stucki M, Flury K, Frischknecht R, Büsser S. Life Cycle Inventories of Photovoltaics. 2012.

[4] Dones R, Bauer C, Bolliger R, Burger B, Faist Emmenegger M, Frischknecht R, et al. Sachbilanzen von Energiesystemen. Final Rep. ecoinvent data v2.0, Dubendorf and Villigen: Swiss Centre for LCI, PSI; 2007.

[5] Conergy Asia. References - Solar Farms n.d. http://asia.conergy.com/solarinstallations/references/ (accessed November 6, 2018).

[6] HOMER Energy LLC. HOMER Pro 2017.

[7] Kabir MR, Rooke B, Dassanayake GDM, Fleck BA. Comparative life cycle energy, emission, and economic analysis of $100 \mathrm{~kW}$ nameplate wind power generation. Renew Energy 2012;37:133-41. doi:10.1016/j.renene.2011.06.003. 